\title{
A review of Silurian discinoid brachiopods from historical British localities
}

\author{
MICHAL MERGL
}

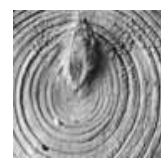

\begin{abstract}
The present article revises descriptions of Silurian discinoid brachiopods by J. de C. Sowerby and T. Davidson in the mid-nineteenth century, and of old collections from classic palaeontological sites in Britain, currently housed in the Natural History Museum, London. Orbicula forbesii Davidson, 1848, O. rugata J. de C. Sowerby in Murchison, $1839, O$. striata J. de C. Sowerby in Murchison, 1839, Discina verneuilii Davidson, 1848 are re-described. The genus Rugadiscina and the species Acrosaccus woolhopensis, Acrosaccus cocksi and Schizotreta walkeri are erected. Discina? cf. rarissima Barrande, 1879 and the genus Lochkothele are documented from the Silurian of Britain for the first time. Although the generic composition of the British Wenlock discinoid fauna is similar to that of the Barrandian area in Bohemia, differences at the species level confirm the separation of these terrains during the Silurian. - Key words: Brachiopoda, Discinida, taxonomy, Silurian, Great Britain, Bohemia.
\end{abstract}

Mergl, M. 2006. A review of Silurian discinoid brachiopods from historical British localities. Bulletin of Geosciences 81(4), 215-236. Czech Geological Survey, Prague. ISSN 1214-1119. Manuscript received September 21, 2006; accepted in revised form November 5, 2006; issued December 31, 2006.

Michal Mergl, University of West Bohemia at Plzeň, Department of Biology, Klatovská 51, 30619 Plzeň, Czech Republic;mmergl@kbi.zcu.cz

Lower Palaeozoic discinoid brachiopods are relatively poorly known, even though they have received some attention from a few workers in recent decades (Bassett 1986, Holmer 1987, Havlíček \& Mergl 1988, Havlíček 1994, Sutton et al. 2000, Mergl 2001). This lack of knowledge is reflected in the revised edition of the Treatise on Invertebrate Paleontology (Holmer \& Popov 2000), in which all the discinid genera are grouped into two families, the Trematidae and the Discinidae.

Many Lower Palaeozoic discinoids were described during the first half of the nineteenth century, but some species have never been fully revised, in particular those of Sowerby (1839) and Davidson (1848, 1866). However, similar species from the Barrandian area of the Czech Republic, mostly erected by Barrande (1879), have been revised recently (Mergl 2001). The present revision of Davidson's specimens, and other material collected mostly in the nineteenth century from the same localities, indicates higher discinoid diversity than previously suggested. While Sowerby (1839) and Davidson (1848, 1866) noted only four species currently referred to discinoids, there are now at least nine recognised species. Davidson $(1848,1866)$ confused some taxa, and although Cocks (1978) critically revised Davidson's material and identified the type specimens, some taxonomic questions remained unsolved. Of particular concern are the species Discina forbesii Davidson, 1848, which is the type species of the genus Orbiculoidea d'Orbigny, 1847, and the species Discina rugata (Sowerby in Murchison, 1839). Both species names have been widely used by other authors and collectors to identify subcircular discinoids of early Palaeozoic age, regardless of the highly variable morphology and various stratigraphical levels involved.

\section{Material}

The present study is a revision of the species erected by Sowerby (1839) and Davidson $(1848,1866)$. The research described here is based exclusively on material stored in the collections of the Natural History Museum in London, and the British Geological Survey in Keyworth. Newer collections have not been considered. The stratigraphic and locality data are often very limited in old material, and do not fit well within the present state of stratigraphic schemes. When possible, old data concerning locality and age have been re-interpreted in accordance with names and stratigraphy presented by Aldridge et al. (2000). However, some of the original stratigraphical and locality information has not yet proved amenable to re-interpretation. The interpretation of stratigraphic and locality data, and the corresponding species ranges, are given in Figs 1 and 2. 


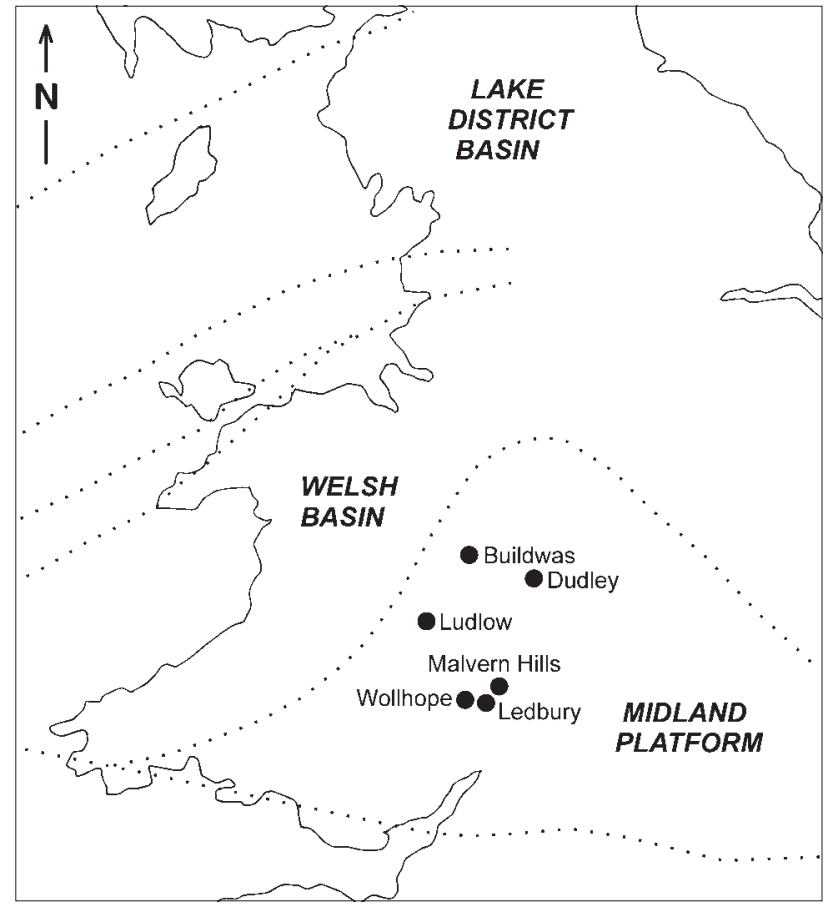

Figure 1. Distribution of historical localities for the Wenlock and Ludlow Series, set against the paleogeographical elements of Silurian Britain. Modified from Aldridge et al. (2000, Figs 4.1, 5.1).

\section{Affinity of the British and Bohemian Silurian discinoids}

Current palaeogeographical reconstruction (Cocks \& Torsvik 2002) locates the Silurian strata of England and Wales in the Avalonian terrain, while the sequence preserved in the Barrandian of Bohemia belongs to the separate microplate of Perunica (Havlíček et al. 1994). It is not surprising that, although separated by an oceanic barrier, similar subtropic palaeolatitudes and shallow marine paleoenvironments are reflected by closely related benthic communities in the Wenlock of Britain and Bohemia (Calef \& Hancock 1974, Watkins 1979, Watkins \& Aithie 1980, Havlíček \& Storch 1990). This similarity in brachiopod communities is also evident among the Wenlock discinoid brachiopods of England and Bohemia. There are pairs of discinid species (Acrosaccus woolhopensis - A. patelliformis, A. cocksi-A. bubovicensis) that represent vicarious species in related palaeocommunities. Schizotreta? rarissima and related species occur in both areas, but the species is not well known in Britain or Bohemia. The encrusting Schizocrania verneuilii is unknown in the Silurian of Bohemia, although this genus does occur there in the Ordovician and rarely also in the Devonian of the region. Lochkothele sp., which is present in the Wenlock of Britain, is represented in the earliest Devonian of Bohemia by abundant L. intermedia (Barrande, 1879). British Wenlock discinoids lived in remarkably rich biostromes of corals, stromatoporoids, bryozo- ans, pelmatozoans, rhynchonelliform brachiopods, and other invertebrate groups in the shallow water environments of an extensive reef that bordered the Welsh Basin. Seven generally medium- to large-sized species lived in that reef: Schizocrania verneuilii, Acrosaccus cocksi, A. woolhopensis, Orbiculoidea forbesii, Lochkothele sp., Schizotreta? cf. rarissima and S. walkeri. In the Barrandian, however, shallow environments were restricted to the apices of submarine volcanoes or along the fringes of temporary volcanic islands. The extent of these shallow water environments was restricted, and they were immediately surrounded by deeper water. Extensive reef complexes were never present in Bohemia, and only small coral-crinoid biostromes were developed locally in the Wenlock and persisted into the Ludlow (Gorstian). Though the large- and medium-sized discinids Acrosaccus patelliformis and A. bubovicensis were uncommon, they were associated with smaller and more diversified discinids including Orbiculoidea karlstejnensis, Schizotreta? rarissima, Schizotreta sp., Acrosaccus vexatum, Ivanothele sp., and other lingulate brachiopods. In contrast to Britain, cemented craniids are rare and Schizocrania is unknown in Bohemia.

In contrast to the Wenlock Series, the more siliciclastic development of the Ludlow Series in Britain was colonised by various discinoids. The discinoid brachiopod diversity subsequently decreased, with only Rugodiscina rugata, and Schizocrania striata present, the latter commonly living in a specific habitat of empty, drifting cephalopod shells (Lockley \& Antia 1980). Similar medium- to large-sized convexoplane discinids and trematids are unknown from the Ludlow of the Barrandian. There, the limestone sedimentation continued into the Ludlow and Pridoli, and there was no substantial siliciclastic input until the Middle Devonian. Numerous small and poorly known discinoids (Acrosaccus, Schizotreta, Ivanothele, Kosoidea, Sterbinella, minute Orbiculoidea) occur in the Ludlow and Pridoli of the Barrandian. The convexo-plane discinoids and Schizocrania appeared in Bohemia during the Early Devonian (Orbiculoidea magnifica, Schizocrania sp.), probably as a consequence of the spread of a more uniform Early Devonian fauna.

\section{Systematic palaeontology}

The materials described in the present paper are from the collections of the Natural History Museum in London (B and BB), the British Geological Survey in Keyworth, Nottingham (BGS and GSM), and the National Museum in Prague (NM L).

Order Lingulida Waagen, 1885

Superfamily Discinoidea Gray, 1840

Family Trematidae Schuchert, 1893 


\section{Genus Schizocrania Hall \& Whitfield, 1875}

Type species. - ?Orbicula filosa Hall, 1847; Trenton Group; Ordovician; New York State, USA.

\section{Schizocrania striata (J. de C. Sowerby, 1839)} Figure 3A-I

1839 Orbicula striata J. de C. Sowerby; Sowerby in Murchison, p. 610, pl. 5, fig. 12.

1854 Orbicula striata J. de C. Sowerby. - Murchison, pl. 20, fig. 3.

1859 Discina striata (J. de C. Sowerby). - Murchison, pl. 20, fig. 3 .

1866 Discina striata (J. de C. Sowerby). - Davidson, p. 6, pl. 6, figs 1-4.

1867 Discina striata (J. de C. Sowerby). - Murchison, pl. 20, fig. 3 .

1872 Discina striata (J. de C. Sowerby). - Murchison, pl. 20, fig. 3 .

1902 Orbicula striata J. de C. Sowerby. - Blake, p. 6.

1963 Schizocrania striata (J. de C. Sowerby). - Holland et al., p. 154.

1978 Schizocrania striata (J. de C. Sowerby, 1839). Cocks, p. 26.

1980 Schizocrania striata (Sowerby). - Lockley \& Antia, text-fig. 2A-C.

Lectotype. - Selected by Cocks (1978), dorsal valve housed at the British Geological Survey in Keyworth, Nottingham (BGS6631), figured by Sowerby in Murchison (1839, pl. 5, fig. 12, right-hand specimen), refigured here in Fig. 3I.

Type horizon and locality. - Silurian, Ludlow, Ludfordian; Upper Ludlow beds; England, Shropshire, Delbury.

Material. - Six specimens in the collection of the Natural History Museum (Baugh collection, dorsal valve B97852, from Linley Brook; T. Davidson collection, two dorsal valves B5895 and B14274, from Ludlow; A. Marston collection, dorsal valve and complete specimen B41659, from Ludlow; G.F. Morton collection, dorsal valve B24092, from Ludlow); two specimens in the collection of the British Geological Survey (dorsal valves BGS6631 and BGS6632, from Ludlow).

Diagnosis. - Medium-sized, circular, convexoplane Schizocrania with rounded dorsal costellae separated by deep interspaces of the same size; intercalated costellae on dorsal valve gradually increase in size; ventral valve with distinct radial costellation.

Description. - The shell is convexoplane, rectimarginate, thin-shelled, medium-sized with the largest known speci-

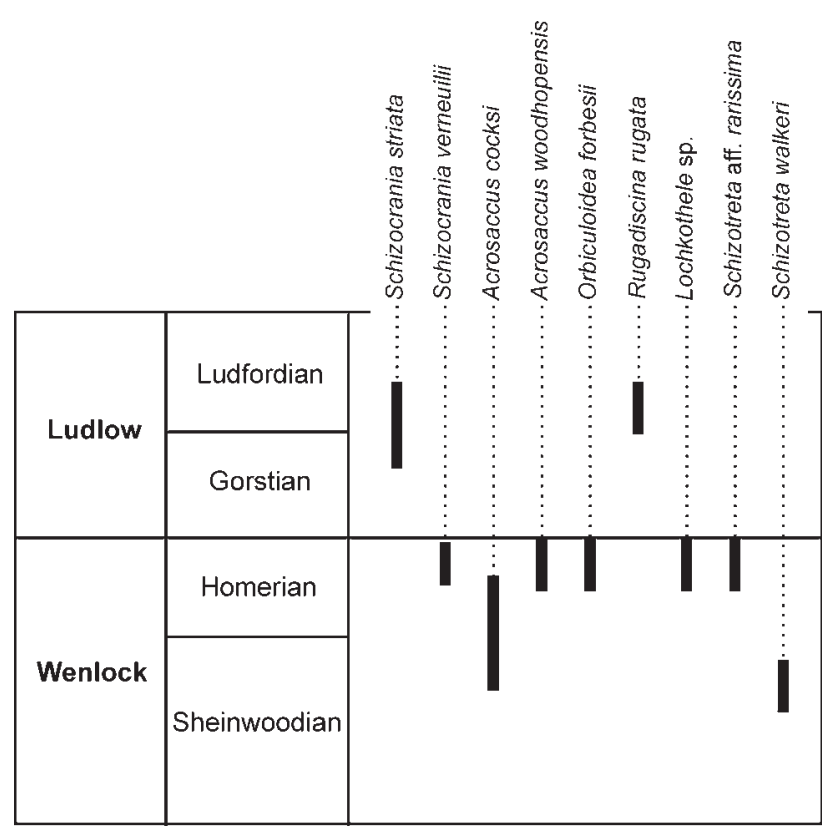

Figure 2. The global Wenlock and Ludlow stratigraphy and ranges of revised British discinoid brachiopods.

men being $18 \mathrm{~mm}$ long. The dorsal valve is subcircular, moderate to strongly convex transversally and longitudinally, with evenly curved margins. The posterior margin is not distinctly thickened. The apex is marginal, blunt. The shell interior lacks any details. The shell is covered by fine, rounded and rather high costellae, separated by deep interspaces of the same size or even narrower than those the bordering costellae. New costellae are fewer, originating by intercalation, and originally narrower than the adjacent older costellae. There are 40-45 costellae per $5 \mathrm{~mm}$ at $5 \mathrm{~mm}$ from the apex, and some 30 per $5 \mathrm{~mm}$ at the anterior margin of the largest-known specimen. Low concentric bands crossing the crest of costellae are unevenly scattered on the shell surface (Fig. 3C). Growth lines are weak, distinct only in interspaces between ribs, densely arranged and curved near bordering costellae.

The ventral valve is flat, with a broadly triangular pedicle opening and the apex situated in posterior third. The shell surface adjacent to the pedicle opening is turned dorsally. Fine growth lines of uneven size, crossed by fine, clearly defined, raised, radial costellae covering the surface of the valve. Costellae are missing in the posterior third of the valve.

Remarks. - The species is similar to Schizocrania verneuilii (Davidson, 1848), but differs in the finer radial ornament of the dorsal valve, with equally wide costellae and interspaces. The interspaces on the dorsal valve of $S$. verneuilii are two to three times broader than the costellae. In addition, the costellae of the ventral valve are denser in S. striata than in $S$. verneuilii. The latter species is also about twice as large. 
The species was erected by Sowerby (in Murchison 1839) and redescribed by Davidson (1866), who commented on its affinity to $S$. verneuilii and figured four specimens (his 1.c. pl. 6, figs 1-4). Figure 1 in his plate 6 is redrawn after the lectotype, and figure 3 is an idealized drawing to show the nature of the ornamentation. None of the specimens in the Natural History Museum's collection can be referred to Davidson's figures 2 and 4. The dorsal valve in figure 2 is twice the size of the specimen referred to this figure by Cocks (1978), but the locality is the same. According to Davidson (1866) the specimen in figure 2 is derived from the collection of Mr. Marston. There are two specimens from Marston's collection in the Natural History Museum (both B41659), but neither can be identified as the specimen in Davidson's figure 2. The first specimen is an incomplete dorsal valve. The second is an external mould of a ventral valve inside the dorsal valve (Fig 3E).

Davidson's figure 4 is the elongate dorsal valve that is twice the size of the specimen referred to this figure by Cocks (1978). Davidson (1866) noted that this specimen came from the collection of Mr. Lightbody, but in the original label attached to the specimen (B5895) in Davidson's handwriting it is labelled "from Rev. H. G. Day". Consequently, this is probably another unfigured specimen. Unfortunately, there is no reference to Discina striata in Davidson's manuscript notebook in the Natural History Museum.

Distribution. - Ludlow, Gorstian and Ludfordian; England, Shropshire, Ludlow.

\section{Schizocrania verneuilii (Davidson, 1848)}

Figure 3J-P

1848 Orbicula Verneuilii Davidson; p. 334, pl. 3, fig. 47.

1866 Discina Verneuilii Dav. - Davidson, p. 68, pl. 6, fig. 5.

1978 Schizocrania verneuilii (Davidson, 1848). - Cocks, p. 26.

Holotype. - By monotypy, the complete shell housed at the British Geological Survey in Keyworth, Nottingham (BGS7820), figured by Davidson (1848, pl. 6, fig. 5), refigured here in Fig. 3O, P.
Type horizon and locality. - Silurian, Wenlock, Homerian; Much Wenlock Limestone Formation; England, Hereford, Ledbury, Stoney Hill.

Material. - Apart from the holotype, 24 specimens in the collection of the Natural History Museum (J. Gray collection, 3 ventral valves B707, B1105, and B9487, dorsal valve B797, and 15 young articulated specimens attached to the shell of the trimerellid Gasconsia transversa (Salter) B809, from Dudley; Johnson collection, 3 dorsal valves and one ventral valve B8922, from Dudley; small ventral valve B17822, from Walsall).

Diagnosis. - Large, circular, convexoplane Schizocrania with rounded, fine, dorsal costellae separated by two- to threefold broader shallow interspaces; intercalated costellae on dorsal valve rapidly reach the size of adjacent primary costellae; ventral valve with distinct radial costellation and narrowly triangular pedicle slit.

Description. - The shell is large, 25-27 mm long in adult forms, convexoplane, thin-shelled, with a regularly circular outline, and rectimarginate commissure. The dorsal valve is moderately convex (all available specimens are deformed) with a marginal, weakly defined apex. The interior lacks any traces of visceral area or muscle scars. The exterior is covered by fine, rounded costellae, arranged in a chevron-like pattern. Costellae are straight in the median sector but become curved posterolaterally. Interspaces are flat-bottomed, two to three times broader than adjacent costellae. The size of costellae and interspaces regularly increase during growth. There are few intercalated costellae. Costellae are undivided, a few new costellae originate exclusively by implantation and they immediately attain the size of the primary costellae. The number of costellae per $5 \mathrm{~mm}$ varies from 30 to 35 , but there are only 11 to 15 on the anterior periphery of adult shells, some reaching $25 \mathrm{~mm}$ in length. Concentric growth lines are very fine, distinct only in the troughs of the interspaces, and are weakly curved toward the apex.

The ventral valve is flat, with the apex in or near the posterior third. The pedicle slit is narrowly triangular, with adjacent shell surface turned dorsally. The shell wall is slightly thickened near the anterior edge of the pedicle slit,

Figure 3. Schizocrania striata (J. de C. Sowerby, 1839). Ludlow, localities Linley Brook (A, H) and Ludlow (B-G, I). A, H - dorsal valve (B97852) with remains of original shell, and lateral view, B97852, both $\times 4.5$. B , F, G - dorsal valve with remains of original shell, detail of ornament, and microornament near anterior margin, B14274, probably original of Davidson (1866, pl. 6, fig. 2), $\times 4.5, \times 6, \times 100 . \cdot \mathrm{C}-$ dorsal valve with original shell showing concentric bands, BGS6632, original of Sowerby in Murchison (1839, pl. 5, fig. 12, left), × 4.5. $\bullet$ D - dorsal valve, B5895, $\times 4.5$. $・$ E - ventral valve inside dorsal valve, external mould, B41659, $\times 4.5$. $・$ I - lectotype, dorsal valve attached to orthocone septum, BGS661, original of Sowerby in Murchison (1839, pl. 5, fig. 12, right), × 4.5. Schizocrania verneuilii (Davidson, 1848). Wenlock, Homerian, Much Wenlock Limestone Formation, localities Dudley $(\mathrm{J}-\mathrm{N})$, and Ledbury (Stoney Hill) $(\mathrm{O}, \mathrm{P}) \cdot \bullet \mathrm{J}, \mathrm{N}-$ ventral valve detail of ornament and complete valve, B797, $\times 11, \times 1.8 \cdot \bullet \mathrm{K}, \mathrm{M}-$ dorsal valve and detail of ornament near anterior margin, $\mathrm{B} 3922, \times 1.8, \times 6 \cdot \bullet \mathrm{L}$-dorsal valve with partly removed shell, B797, $\times 1.8 . \bullet \mathrm{O}, \mathrm{P}-$ holotype, complete shell, ventral valve external mould and ventral valve with partly exfoliated shell, BGS7820A, original of Davidson (1866, pl. 6, fig. 5), $\times 3.8, \times 1.8$. 

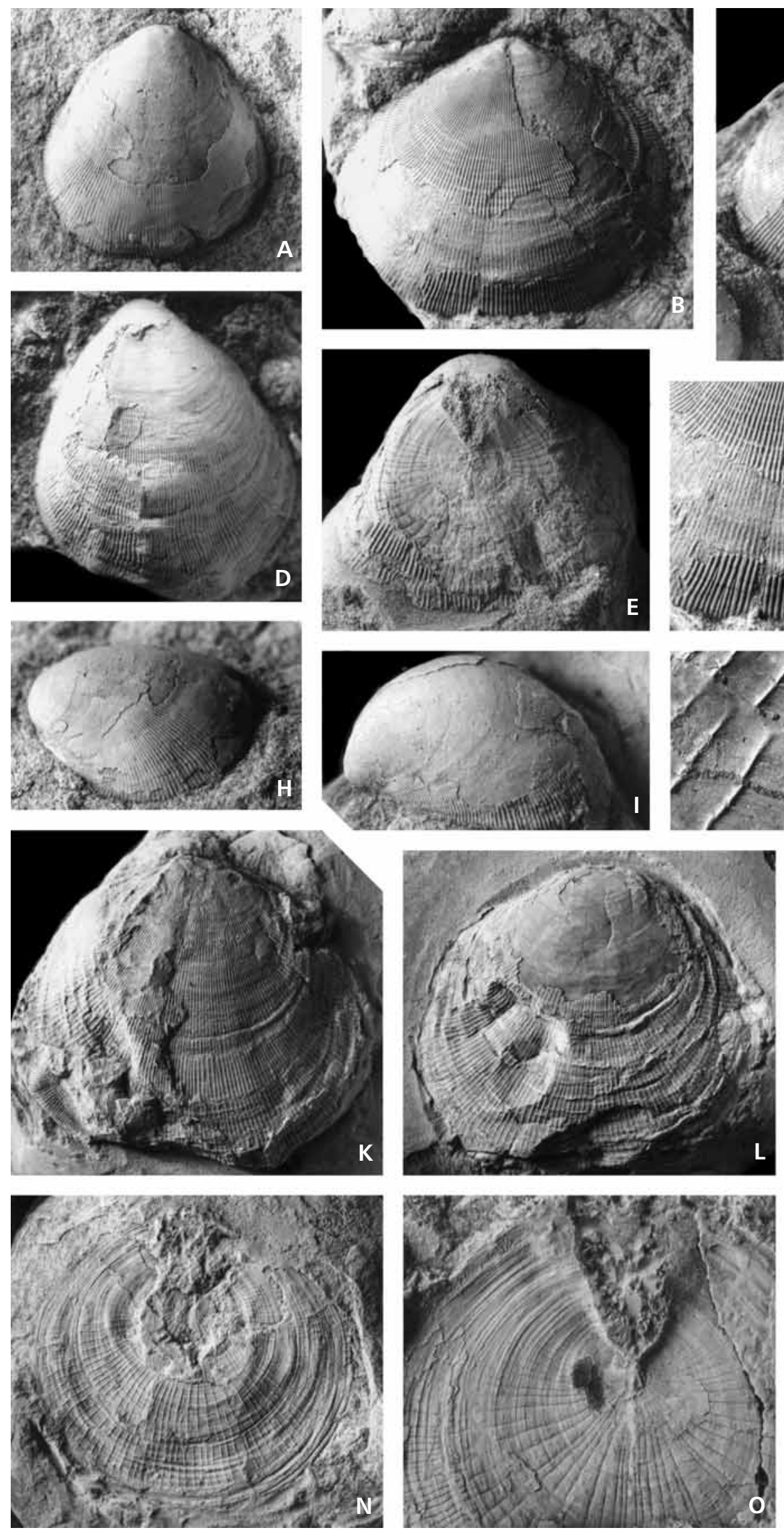
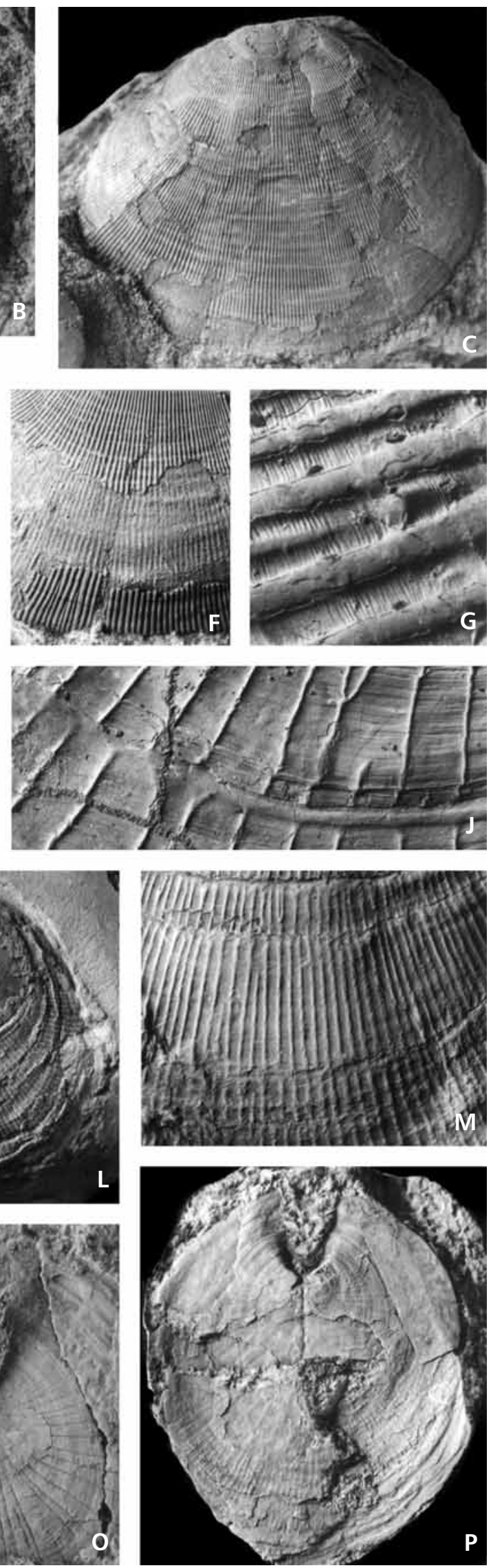
and this continues as a low, elevated ridge in the valve interior below and anterior from the apex. The valve exterior is covered by fine, densely arranged, uneven concentric growth lines that become more distinct and less regular posteriorly. Radial costellae are thinner and fewer than those on the dorsal valve, and are unevenly spaced. In general, there are only one to two ventral costellae opposite of the three to four dorsal costellae along the anterior margin in the measured specimens. Correspondingly, the interspaces are much broader in the ventral valve. New costellae appear (but not commonly) by intercalation; abrupt junction of two adjacent costellae is common. The costellae reach the shell periphery only anteriorly and laterally. In the posterolateral sector, the costellae subsequently disappear during growth, and the shell surface adjacent to the pedicle slit lacks any radial ornament.

Remarks. - Schizocrania verneuilii (Davidson, 1848) is the only Schizocrania species of Wenlock age that is well known. It differs from all Ordovician species of Schizocrania (Reed 1917, Cooper 1956, Havlíček 1972, Williams 1974, Sutton et al. 2000, Mergl 2002) in the unusually broad interspaces between the costellae on the dorsal valve. Bassett (1986) has given the only modern revision of Silurian species, based on a study of material from France originally described by Barrois et al. (1922). As stated by Bassett (1986), it is unlikely than any specimens from that collection belong to $S$. verneuilii.

Davidson (1848) erected the species based on one articulated specimen. The specimen is described as having an outline that is longer than wide, and not significantly deformed. However, the outlines of all the other studied specimens are approximately circular. It is remarkable that the lectotype has the dorsal valve rotated $180^{\circ}$ to the ventral valve. Davidson (1866, p. 68) expressed some doubts about the validity of the species, noting that "it is possible, that the much larger shell I described in 1848 by the name Discina Verneuilii from the Wenlock limestone, may be a full-grown specimen of a variety of Sowerby's species" [=Schizocrania striata (J. de C. Sowerby in Murchison, 1839)]. However, Schizotreta striata is smaller and differs in its densely costellated dorsal valve.

Distribution. - Wenlock, Homerian; Much Wenlock Limestone Formation; England, West Midlands, Dudley and Walsall.

Family Discinidae Gray, 1840

\section{Genus Acrosaccus Willard, 1928}

Type species. - Acrosaccus schuleri Willard, 1928; Ordovician, Caradoc; Virginia, U.S.A.

\section{Acrosaccus cocksi sp. $\mathbf{n}$.}

Figure 4A-P

?1866 Discina rugata Sow. (sp.). - Davidson, p. 63, pl. 5, fig. 18.

1965 Orbiculoidea forbesi (Davidson). - Rowell, p. H 285, fig. 178,7 .

2000 Orbiculoidea? forbesii (Davidson). - Holmer \& Popov, p. 90 , fig. $43,2 \mathrm{a}-\mathrm{c}$.

Holotype. - Ventral valve, figured in Fig. 4J, L, M, P, stored in the palaeontological collection of the Natural History Museum, London (B3926).

Paratype. - Dorsal valve, figured in Fig. 4C, K, stored in the palaeontological collection of the Natural History $\mathrm{Mu}-$ seum, London (B9486c).

Type horizon and locality. - Silurian, Wenlock, Sheinwoodian-Homerian; Wenlock Shale (probably Coalbrookdale Formation); England, West Midlands, Dudley, Wren's Nest.

Name. - After Dr. L.R.M. Cocks of the Natural History Museum, London.

Material. - Fifteen dorsal and 21 ventral valves, from various collections in the Natural History Museum (48737, 48737A, 48737B, B2323, B344890, B34890A, B34890B, B3926, B3926A, B3926B, B3926B, B3926C, B3926D, B815, B815A, B815B, B815C, B815D, B9485, B9486, B9486, B9486A, B9486B, B9486C).

Diagnosis. - Medium-sized, equally biconvex, relatively thick-shelled Acrosaccus with ventral apex between posterior third and mid-length, dorsal apex near the centre; pedicle track posteriorly encloses acute angle; anterior slope concave; exterior with rugellae of uneven size, separated by narrow interspaces.

Description. - The shell is equally biconvex, rectimarginate, $13 \mathrm{~mm}$ wide in large specimens. The shell is remarkably thick relative to its shell size. Outline is circular, with evenly curved margins and length/width ratio near 1.0. The maximum width is at the mid-length. The dorsal valve is conical; its height is $30 \%$ of its width, with a low apex situated slightly posterior to the mid-length or less commonly near the centre. The apex is directed slightly posterodorsally, with the larval shell elevated above the surrounding shell surface. The posterior slope is straight in lateral profile. The anterior slope is convex, and steeper anteriorly than posteriorly; the flanks are slightly convex. The dorsal valve has a small, poorly defined visceral field, with minute oblique scars of the anterior adductor. Pallial mar- 
kings are weakly impressed, with numerous rarely branching radial canals.

The ventral valve is asymmetrically conical; its height is $35-40 \%$ of its length, with a prominent apex between the posterior third of the valve and the mid-length, with the top directed anteroventrally. The posterior slope is moderate, but in large valves steeply sloping, with a convex lateral profile. The anterior slope has a nearly straight profile, with a weak concavity near the apex. Flanks are slightly convex. The pedicle track is spindle-shaped, slightly tapering anteriorly, occupying one-third of the posterior slope in adults but almost half in medium-sized specimens. The external pedicle opening is small. The bottom of the track is closed by a distinct listrial plate. It has a moderately sloping outer part bearing anteromedianly curved growth lines, and a rough narrow median plate. The ventral interior has a very short pedicle tube, with a large subcircular pedicle opening posteriorly. The muscle scars are not discernible. Pallial markings are weakly impressed, with numerous fine, radially disposed canals.

The ornament consists of densely packed, and in some places somewhat irregular concentric rugellae, which are low, rounded, variable in a size, and separated by narrower interspaces. There are 25 to 40 rugellae per $5 \mathrm{~mm}$ in the mid-length of the large valve.

Remarks. - The new species is very similar to Acrosaccus bubovicensis (Mergl, 2001) from the Wenlock (Sheinwoodian) of Bohemia. Acrosaccus bubovicensis shares a thick shell wall, a reduced internal pedicle tube, an anteroventrally turned ventral apex, and its surface bears similarly densely spaced and fairly regular rugellae. The size of both species are similar. However, Acrosaccus bubovicensis differs from $A$. cocksi in its more anteriorly situated dorsal apex, and in the clearly elongate shell outline with length/width ratio about 1.1. Acrosaccus schuleri Willard, 1928 differs mainly in its submarginal dorsal apex and smaller size.

Acrosaccus cocksi has been repeatedly confused with the species Orbiculoidea forbesii (Davidson, 1848) (Rowell 1965a, Holmer \& Popov 2000). The new species differs from $O$. forbesii in its smaller size, relatively thickwalled shell, shorter pedicle track, higher convexity of the ventral valve but lower convexity of the dorsal valve, and by a different external ornament. The ornament of $A$. cocksi sp. n. consists of coarse, uneven, sturdy rugellae, while that of $O$. forbesii consists of thin raised rugellae separated by wider, flat interspaces.

Although the original specimen of Davidson (1866, pl. 5, fig. 18) referred by him to Discina rugata (J. de C. Sowerby) (= Rugadiscina rugata) has not been located in any of the collections and is probably lost (Cocks 1978), this valve might belong to $A$. cocksi. This dorsal valve shows a more centrally situated apex than is usual in
R. rugata. In addition, it would be the only valve of $R$. rugata figured by Davidson (1866) of Wenlock age.

Almost all specimens in the Natural History Museum are labelled 'Wenlock Limestone', 'Wenlock shale' or 'Wenlock', and derive from Dudley. The specimens studied here are preserved in grey to greenish-grey shale, probably the Coalbrookdale Formation (Wenlock, Sheinwoodian and Homerian), though some specimens may have originated from the stratigraphically higher mudstones of the Much Wenlock Limestone Formation. Four specimens from the collection of S. Allport, dated 1873 (B80420), are labelled Orbiculoidea rugata from 'Lower Ludlow beds' (probably lower Elton Formation) of Dudley, but this stratigraphic reference cannot be verified and is therefore dubious.

Distribution. - Wenlock, Sheinwoodian and Homerian; Coalbrookdale Formation and probably also Much Wenlock Limestone Formation; England, West Midlands, Dudley, Wren's Nest.

\section{Acrosaccus woolhopensis sp. $\mathbf{n}$.}

\section{Figure 5A-N}

1848 Orbicula Forbesii Davidson; Davidson, p. 334, pl. 3, fig. 45 (second from right, not upper and third and first from right).

1848 Orbicula Forbesii Davidson. - Phillips \& Salter, p. 371 , pl. 26, fig. 2.

1866 Orbiculoidea Forbesii Dav. 1848. - Davidson, p. 73, pl. 7, figs 14, 15, not 16-18.

1917 Orbiculoidea (Schizotreta?) Forbesi (Davidson). Reed, p. 821, pl. 4, fig. 25.

?1950 Orbiculoidea (Schizotreta?) forbesi (Davidson). Whittard \& Barker, p. 556, pl. 5, fig. 1.

1978 Orbiculoidea forbesii (Davidson, 1848). - Cocks, p. 27.

Holotype. - Ventral valve, refigured on Fig. 5A, D, F, H, stored at the British Geological Survey in Keyworth, Nottingham (GSM16538), the same specimen figured by Phillips \& Salter (1848, pl. 24, fig. 2) and refigured by Davidson (1866, pl. 7, figs 14, 14a, 14b).

Type horizon and locality. - Silurian, Wenlock, Homerian, Much Wenlock Limestone Formation; England, Hereford, Woolhope Inlier, Dormington.

Name. - After the type locality.

Material. - Ten specimens in the collections of the Natural History Museum (T. Davidson collection, ventral valve B14289, from Malvern Hills; Dyson collection, ventral valve B34793, dorsal valve B34793, and dorsal valve 
B34793 from Malvern Hills; J. Gray collection, two ventral valves B796, from Malvern Hills; H.B. Holl collection, ventral valve B4065, from Malvern Hills; G.H. Piper collection, ventral valve B10079 from Ledbury; B.M. Wright collection, dorsal valve B47930, from Malvern Hills; dorsal valve B8427, from Dudley), and four specimens in the collections of the British Geological Survey (ventral valves BGC2314, GSM16537, GSM16539 from Malvern Hills, GSM16538 from Woodhope Inlier).

Diagnosis. - Large ventribiconvex, relatively thin-shelled Acrosaccus with ventral apex in posterior third, dorsal apex subcentral; pedicle track posteriorly enclosed at an acute angle; shell interior with very small, poorly defined visceral area and weak pallial markings; exterior uniformly, regularly and finely rugellate with rounded interspaces of uniform size.

Description. - The shell is ventribiconvex, rectimarginate, and large, with lengths from 25 to $27 \mathrm{~mm}$ in adult specimens. The shell wall is thin relative to shell size. The outline of the shell is broadly oval to subcircular, generally regular, sometimes with gentle asymmetry in the posterior part. Margins are evenly curved, also posteriorly. The length/width ratio generally varies between 1.04-1.08, with the lowest at 0.96 . The maximum width is at mid-length.

The dorsal valve is low, depressed and conical, with straight slopes. The valve height is less than $10 \%$ of the length. The apex is eccentric, situated on the posterior $40 \%$. The interior of the valve has a relatively small and weakly defined visceral area (Fig. 5M). The muscle impressions are weakly defined, with small, undivided scars of the posterior oblique muscles, a pair of undivided smaller muscle scars posterolaterally (probably the sites of posterior adductors and oblique internal muscles), and oblique, narrowly triangular and relatively large anterior adductor scars (Fig. 5L). A distinct anterior projection extends between the inner borders of the anterior adductor scars. A short, thin myophragm is present in the apical part. Pallial markings are not well preserved apart from the proximal part of the vascula lateralia, but the intervascular ridges are clear along the shell periphery of partly exfoliated shells (Fig. 5I).

The ventral valve is asymmetrically and moderately conical, with the apex located between posterior one-third to one-fourth (Fig. 5A-C). The profile of the anterior slope changes from straight with weakly concave apical part to poorly convex. The posterior slope is much steeper and always moderately convex. The lateral slopes are straight to weakly convex. The pedicle track occupies $40-45 \%$ of the posterior slope. It is spindle-shaped, $6 \mathrm{~mm}$ long, and $1.4 \mathrm{~mm}$ wide in the holotype. The margins of the posterior extremity of the pedicle track subtend an acute angle. The bottom of the pedicle track is broadly angular in cross section, with broader, sloping outer parts and narrower, nearly linear, rough bottom. The sloping parts are covered by anteromedianly curved, fine growth lines. The interior of the valve lacks prominent muscle impressions apart from a pair of incipient anterior adductors and very small imprints of oblique internal muscles. Both pairs lie immediately anterior to the ventral apex.

The ornament of both valves is prominent and uniform in all specimens studied. The dorsal valve bears generally uniformly-sized growth rugellae with stout bases, separated by similarly wide, rounded interspaces (Fig. 5K). The ventral valve has similar rugellae over the entire surface. Only near the apices does the size and density of rugellae decrease. In general, the rugellae are uninterrupted, regularly curved, and undivided. Sometimes interruptions or other irregularities have been caused by injury of the mantle lobe, thus forming drapes, bare surfaces or wavy shapes in some rugellae. The new rugellae are scarce and originate exclusively by intercalation in the lateral sectors of the shell. There are 17 to 22 rugellae per $5 \mathrm{~mm}$ at the mid-length of large valves. Concentric lamellae are less prominent, overlapping the adjacent shell surface, and are almost regularly spaced: there being 4 to 6 in large shells. Radial ornament is absent in all but one valve, which displays divergent, radial, superficial, rayed striation in the median sector. Microornament has not been observed.

Remarks. - The new species is closely related to the species Acrosaccus patelliformis (Barrande, 1879) from the Wenlock (Motol Formation, Sheinwoodian) of Bohemia (Mergl 2001). Both species have a similar size and outline. The main difference concerns the location of the ventral apex, which is more centrally situated in A. patelliformis. The convexity of the ventral valve of $A$. patelliformis is also less prominent. The ornament of $A$. woolhopensis is coarser, with stout bases of the rugellae, while their bases are thinner and only the crests of rugellae are thickened in

Figure 4. Acrosaccus cocksi sp. n. Wenlock, Homerian, Wenlock Shales (probably the Coalbrookdale Formation), Dudley locality. $\bullet$ A - small dorsal valve, B9486a, $\times 4.0 . \bullet B, E-$ small dorsal valve, oblique and dorsal views, B48737a, both $\times 4.0 . \bullet$ C - dorsal valve with exfoliated apex, B9486b, $\times 4.0$. $\mathrm{D}, \mathrm{K}$ - dorsal valve and lateral view, B9486c, both $\times 4.0 \cdot \bullet \mathrm{F}-$ small ventral valve, B48737b, $\times 4.0$. $\bullet \mathrm{G}-$ ventral valve, B815, $\times 4.0$. $\bullet \mathrm{H}, \mathrm{M}-\mathrm{ventral}$ valve, ventral and oblique views, B48737, both $\times 4.0$. $\bullet$ I - large ventral valve with subcentral apex, ventral view, B24129, $\times 4.0$. $\bullet$ J, L, P - ventral valve with posterior apex, ventral and posterolateral views, and detail of ornament, B3926 $\times 4.0, \times 4.0, \times 36$. $\bullet \mathrm{N}, \mathrm{O}-$ small ventral valve showing pedicle track and anteroventral facing of ventral apex, ventral and oblique views, B815, both $\times 14$. 

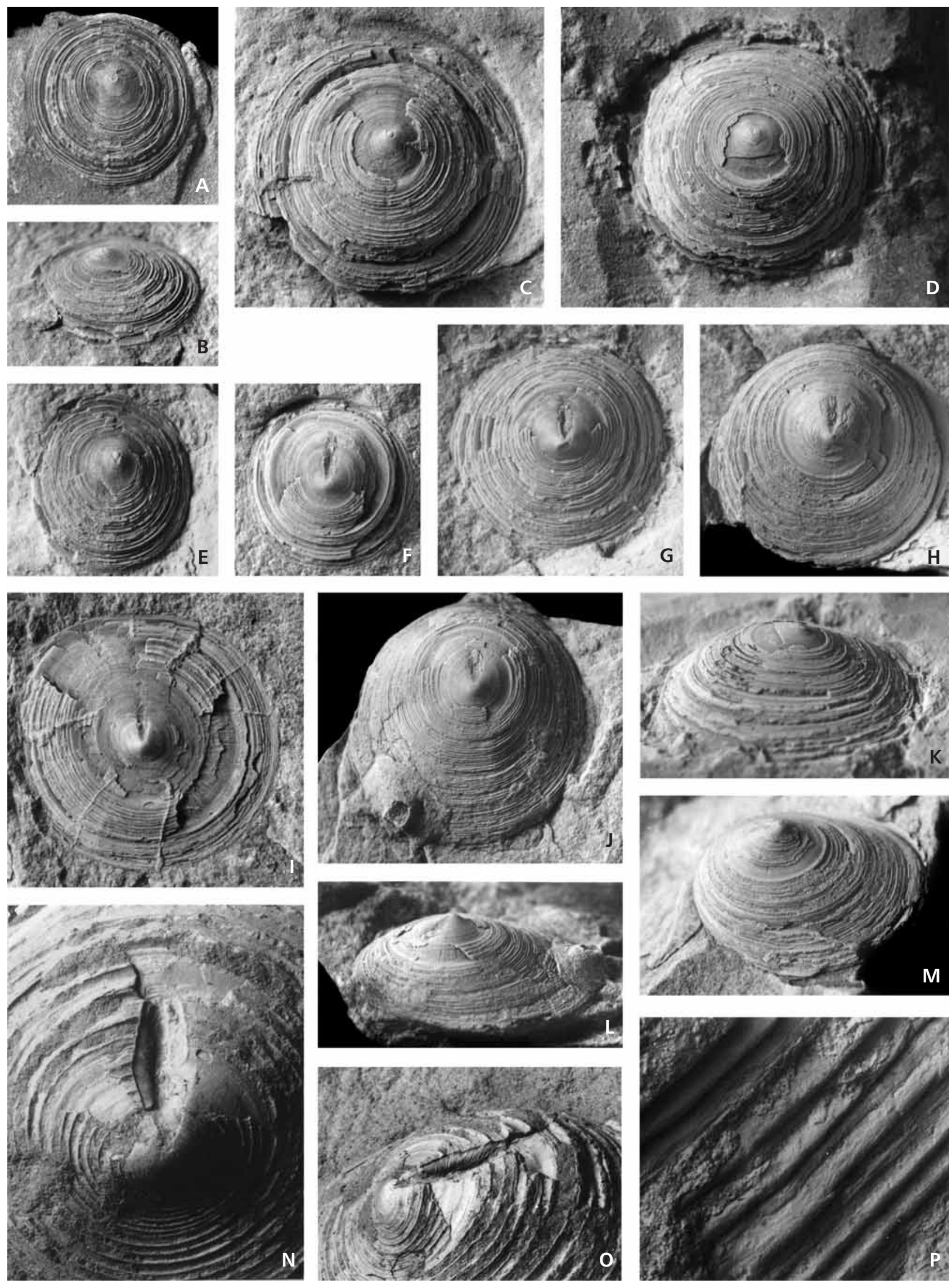
A. patelliformis. The Ordovician Acrosaccus schuleri Willard, 1928 differs in having a submarginal dorsal apex and smaller size.

The new species has been confused with Orbiculoidea forbesii (Davidson, 1848) by some authors (Phillips \& Salter 1848, Davidson 1866, Cocks 1978). The affinity of both species is commented on in the remarks to Orbiculoidea d'Orbigny, 1847.

In the holotype, the ventral valve figured by Phillips \& Salter (1848) and by Davidson (1866, pl. 7, figs 14, 14a, $14 \mathrm{~b}$; in his notebook is written "figured in Phillips") has unique morphology in the posterior part of the pedicle track (the diverging grooves in Davidson's figure 14b), and so it cannot be confused with any other specimen among the historical collections and figured specimens. It is noteworthy that the shell outlines considerably differ in these drawings. Phillips \& Salter (1848) presented an almost circular shell outline, while it is much elongated in Davidson's (1866) figure. This is the result of different interpretations of the crushed anterior part of the valve (Fig. 5A).

Davidson $(1866$, pl. 7, figs 14, 15) stated the locality of both illustrated ventral valves to be Winnal's Farm, Malverns, but his notebook includes partially different data. The holotype (GSM16538) has the locality stated as "Dormington House, Woolhope", from Davidson's note adjacent to the original drawing. These drawings (the valve, detail of pedicle track, and the lateral profile of the valve) are based on the specimen or drawing in which the locality "Dormington-Wood, Woolhope" is also noted (Davidson 1866, p. 74). The second ventral valve (GSM16537) in figure 15 is noted as "Wenlock limestone, Malverns". The original numbers of the Museum of the Geological Survey (19/53 and 19/52 respectively) are attached to Davidson's manuscript drawings of both valves, and their identity with the specimens is unambiguous. Another Davidson manuscript note, written to the left of the pictures, concerns another, probably unfigured specimen from the collections of the Geological Survey: "It occurs also in Wenlock limestone of Winnal's Farm, Malvern." This specimen might be identical with the ventral valve in the British Geological Survey (GSM16539), but it also might be the specimen in Davidson's collections at the Natural History Museum (B14289). The label attached to the latter specimen also has the locality "Winnal Farm,
Malvern", with a note "given to me by Mr. Rev. J. Dyson". In the collections of the Natural History Museum in London, this specimen is currently marked as the type specimen figured by Davidson (1866, pl. 7, fig. 14). However, it is unlikely that Davidson ever figured these specimens in 1848 or 1866 . There are other specimens in the collections of the Natural History Museum from Winnal's Farm, Malvern, in the collection of J. Dyson, which Davidson did not figure.

Distribution. - Wenlock, Homerian; Much Wenlock Limestone Formation; Welsh Borderland, Hereford, Malvern Hills; Woolhope Inlier, Dormington; West Midlands, Dudley, Wren's Nest.

\section{Genus Orbiculoidea d'Orbigny, 1847}

Type species. - Orbicula forbesii Davidson, 1848; Silurian, Wenlock; West Midlands, England.

Diagnosis (emended). - Shell strongly dorsibiconvex, subcircular, with subtrapezoidal outline of the posterior shell part; shell thin-walled; ornament of both valves composed of regular raised concentric fila separated by broader interspaces; dorsal valve conical to subconical with subcentral apex; ventral valve depressed conical with subcentral apex; pedicle track narrow, tapering posteriorly, anteriorly closed by shallow listrium; foramen in posterior end of listrium with short internal tube.

Remarks. - Acrosaccus Willard, 1928 differs from Orbiculoidea d'Orbigny, 1847 in its low dorsal valve with submarginal apex and its high conical ventral valve. Schizotreta Kutorga, 1848 differs from Orbiculoidea in its elongate oval outline, short pedicle track and long internal pedicle tube. Roemerella Hall \& Clarke, 1890 differs from Orbiculoidea by having a pedicle track on a broadly elevated area, but shares a high conical dorsal valve and ornament. Roemerella is poorly known and could be a synonym of Orbiculoidea. Gigadiscina Mergl \& Massa, 2005 differs from Orbiculoidea in its very short pedicle track and its much large size, but the ornament, shell outline and convexity indicate the close affinity of both genera.

Figure 5. Acrosaccus woolhopensis sp. n. Wenlock, Homerian, Much Wenlock Limestone Formation, localities Woolhope Inlier, Dormington (A, D, F, H), Malvern (B, C, E, G, I, J, N), Dudley (K-M). • A, D, F, H - holotype, damaged ventral valve in ventral (A) and oblique (F) views, and detail of pedicle track in oblique (D) and posteroventral (H) views, GSM 16538, the specimen figured by Phillips \& Salter (1848, pl. 26, fig. 2) as Orbicula Forbesii Davidson, and re-figured by Davidson as Orbiculoidea forbesii Davidson (1866, pl. 7, fig. 14). Note malformed posterior of the pedicle track with diverging scars, figured both Phillips \& Salter (1848) and Davidson $(1866), \times 1.7, \times 4.5, \times 1.7, \times 4.5 \cdot \bullet B, G-$ ventral valve, ventral and lateral views, GSM2314, both $\times 1.7$. $\bullet$, J - ventral valve with posterior apex and its side view, B34793, both $\times 1.7$. $\bullet$ E - ventral valve, apex showing pedicle track and its angular posterior termination, B796, $\times 1$.7. $\bullet \mathrm{I}-$ dorsal valve, with partly exfoliated shell showing pallial markings, B34793, $\times 1.7$. $\bullet \mathrm{K}-\mathrm{M}-$ dorsal valve with partly exfoliated shell (M) showing muscle scars $(\mathrm{L})$ and detail of ornament $(\mathrm{K}), \mathrm{B} 8427, \times 11, \times 9.0, \times 1.7 . \bullet \mathrm{N}-$ dorsal valve, external mould, B47930, $\times 1.7$. 
Michal Mergl • British Silurian discinoid brachiopods
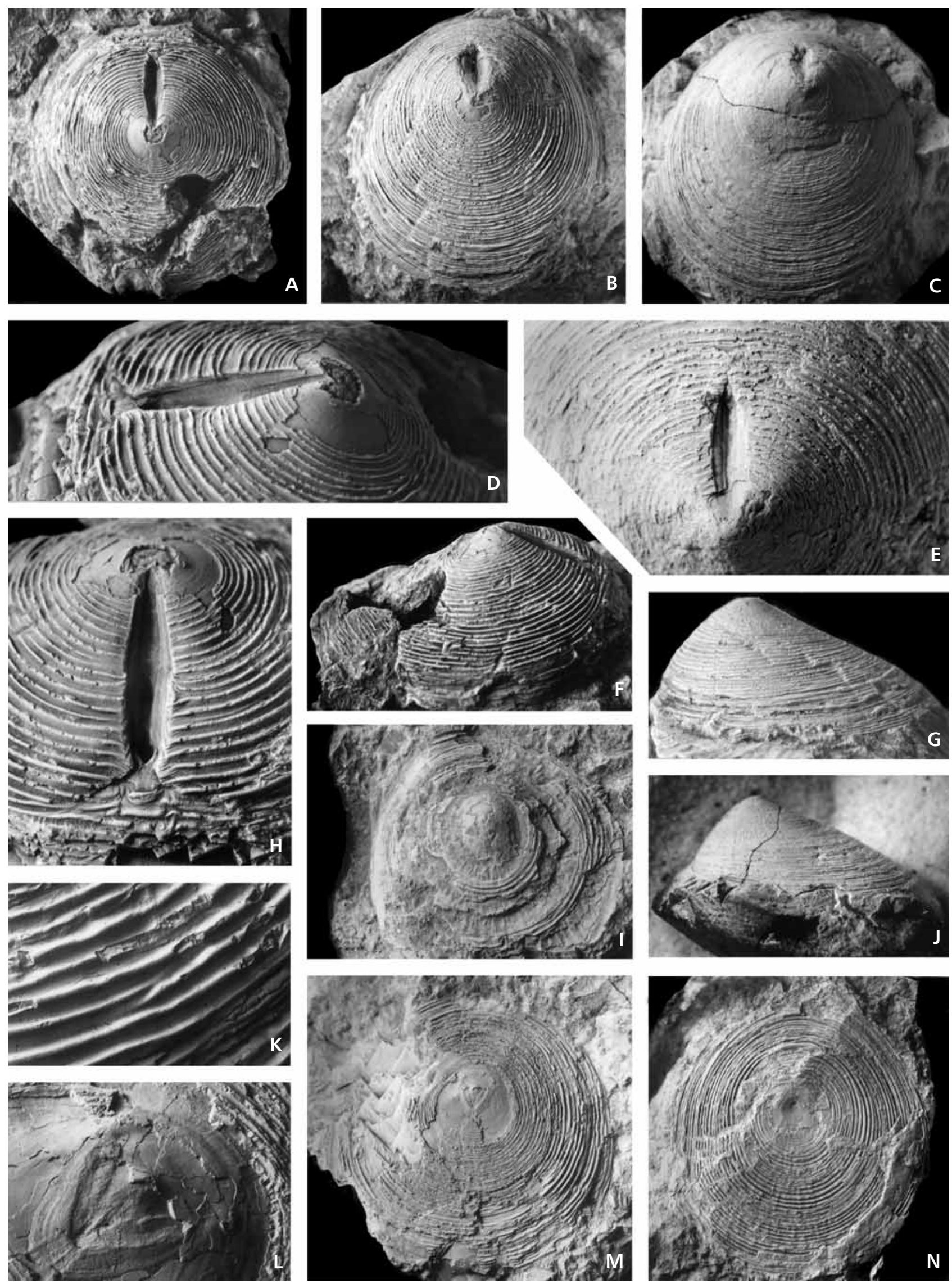
As stated by Rowell (1962), the type species of the genus has long been Orbicula morrisii Davidson, 1848. However, because this species is a craniid, the same author subsequently designated the species Orbicula forbesii Davidson, 1848 as the type species of Orbiculoidea d'Orbigny, 1847. The material of $O$. forbesii has been revised during the present author's study of British Lower Palaeozoic discinoids. This reveals that two different discinid species have been under the name $O$. forbesii. The second of them is described here as the new species Acrosaccus woolhopensis $\mathrm{sp} . \mathrm{n}$.

In 1848, when the type species Orbiculoidea forbesii (Davidson, 1848) was erected, two articles with the name Orbicula forbesii were published. However, Thomas Davidson first used this species name in 1848 in an unpublished volume of the London Geological Journal. This first unpublished report resulted in the attribution of another valve to this species by Phillips \& Salter (1848). Their statement that "Mr. Davidson is about to describe and figure the species fully" indicates that these authors were familiar with Davidson's unpublished report. In the same year, Davidson (1848) described and figured other valves under the name Orbicula forbesii; this report was presented on May 8, 1848 but the exact date of publication is unknown. The exact publication date of Phillips's \& Salter's (1848) paper is also unknown (BGS written communication, August 2005). Consequently, according to the ISZN Rules, the December 31, 1848 is the date of publishing of both works. However, it seems reasonable to consider the priority of Davidson's (1848) paper, supported by his statement (Davidson 1866, p. 74). The dorsal valve figured by Davidson (1848) in pl. 3, fig. 45, left top, left bottom, and ornament detail, is thought to represent the typical morphology of Orbiculoidea forbesii, and it is the first and only published report of this species from 1848.

The ventral valve figured by Davidson $(1848$, pl. 3, fig. 45 , the second from right), selected as the lectotype of O. forbesii by Cocks (1978), belongs to another species, probably Acrosaccus woolhopensis sp. n. The identification of Davidson's (1848) specimens among his collection is problematic (Cocks 1978). Another ventral valve figured by Phillips \& Salter (1848) and ventral valves figured by Davidson (1866, pl. 7, figs 14, 15) belong to Acrosaccus woolhopensis. The only dorsal valve of Orbiculoidea forbesii figured by Davidson (1866, pl. 7, fig. 16), possibly the same specimen that he figured in 1848 (pl. 3, fig. 45 upper and third from right and detail), has not been identified in any collection, as already stated by Cocks (1978). The identity of an articulated specimen (Davidson 1848, pl. 3, fig. 45 , right bottom) is thus uncertain.

Therefore, the neotype is selected from the material stored at the Natural History Museum in London. The neotype, an articulated specimen from Gray's collection, probably from Dudley (collector name and original locality noted by Davidson 1848, p. 334), could be identical with the specimen already figured by Davidson (1848; pl. 3, fig. 45, first from right), but this cannot be independently verified.

Species referred. - Apart from the type species, a few other comprehensively described species can be referred to Orbiculoidea; the majority of species formerly referred to $\mathrm{Or}$ biculoidea from the Ordovician, Silurian and Devonian belong to Acrosaccus Willard, 1928. Among discinoids from the Barrandian area, only Orbiculoidea magnifica Mergl, 2001 from the Lochkov Formation (Lochkovian) corresponds to the emended diagnosis of Orbiculoidea. It has a long pedicle track, much shorter than that of Gigadiscina Mergl \& Massa, 2005.

\section{Orbiculoidea forbesii (Davidson, 1848)}

Figure 6A-O

1848 Orbicula Forbesii Davidson; Davidson, p. 334, pl. 3, fig. 45 (top, upper detail, first and third from right, not second from right).

1866 Orbiculoidea Forbesii Dav. 1848. - Davidson, p. 73, pl. 7, fig. 16 .

1978 Orbiculoidea forbesii (Davidson, 1848). - Cocks, p. 27 (pars).

Neotype. - Complete shell, shown in Fig. 6B, C, E, O, stored in the palaeontological collection of the Natural History $\mathrm{Mu}-$ seum in London (B818), and its counterpart (B796), probably the specimen figured by Davidson (1848) on pl. 3, fig. 45 (first from right) and refigured by Davidson (1866) on pl. 7 , fig. 16a, bottom (non 16a top).

Type horizon and locality. - Silurian, Wenlock, Homerian; Much Wenlock Limestone Formation; England, West Midlands, Dudley.

Material. - Ten specimens in the collections of the Natural History Museum (S. Allport collection, ventral valve B80420, from Dudley; Dyson collection, dorsal valve B34793, from Malvern; R. Etheridge collection, dorsal valve B74389 and complete shell B74389 from Malvern; J. Gray collection, ventral valves B796, from (?) Malvern, and complete shell B818 from Dudley; C. Ketley collection, ventral and dorsal valve, B47850 c and d, from Dudley; B.M. Wright collection, ventral valve B47929, from Dudley; dorsal valve, B8427, from Dudley).

Description. - The shell is strongly dorsibiconvex, rectimarginate, with a high semi-globose dorsal valve and very low conical ventral valve, 25-26 mm long, and thin-shelled relative to shell size. The outline is almost circular, with less rounded posterior flanks and slightly extended poste- 
rior margin, forming a subtrapezoidal outline of posterior half of the shell. The length/width ratio is nearly 1.0, with the maximum width slightly anterior to the mid-length.

The dorsal valve is strongly convex and semi-globose, with the apex directed posteriorly, located in the posterior third. The posterior slope is almost straight, the anterior slope is evenly arched and anteriorly almost perpendicular to the commissure plane. Lateral slopes are gently convex, but posterolateral slopes are depressed and almost straight. The dorsal valve interior is poorly known, without distinct muscle impressions, and with a very thin, short median ridge near the apex.

The ventral valve is very low, asymmetrically conical, with the apex directed anteroventrally and located in the posterior $40 \%$ of the valve length. The posterior slope is weakly and evenly convex, anterior slope is shallow and flanks are weakly concave in transverse profile. The pedicle track is narrowly spindle-shaped, occupying half of the posterior slope, with an acute angle in its posterior extremity, and with a posterior external pedicle opening. The bottom of the track is covered by the listrium. The sides of the listrial plate are weakly sloping, covered by uneven, anteromedianly turned growth lines. The surface of the listrium is slightly below the adjacent shell surface, separated by an acute, slightly overhanging shelf. The ventral valve interior lacks a distinct visceral area and the vascular system is poorly impressed.

The ornament of the dorsal valve consists of concentric rugellae, more regularly arranged near the apex, becoming less regular toward the margins. Rugellae are low, rounded with stout bases, 10-12 in number per $5 \mathrm{~mm}$ in anteromedian part of the dorsal valve. The ventral valve is covered by more regular concentric rugellae, arranged at regular distances and separated by broadly U-shaped interspaces. Microornament is poorly preserved, but consists of shallow circular pits without any regular distribution pattern. The pits are of uniform size and 3 to $5 \mathrm{~mm}$ in diameter.

Remarks. - There are only a few comprehensively described species with comparable morphology. Mergl (2001) described several convexoplane discinids from the Barrandian, but all are of Lower Devonian age. Of these, the species Orbiculoidea magnifica Mergl, 2001 (Lochkovian, Lochkov Formation, Radotín Limestone) differs in its entirely planar ventral valve, and a nearly smooth dorsal valve lacking rugellae. O. sp. A (Mergl 2001, pl. 13, figs 9, 12, 13) (Pragian, Koněprusy Limestone) is weakly conical, and in profile has an identical ventral valve, but otherwise it is poorly known. There are similarly shaped but even larger discinids formerly referred to Orbiculoidea from Lower Devonian siliciclastic rocks. These species [Orbiculoidea falklandensis Rowell, 1965b; O. collis Clarke, 1913, and $O$. anomala (Kayser, 1892)] have recently been referred to Gigadiscina Mergl \& Massa, 2005. They have enti- rely flat ventral valves, and shorter and wider pedicle tracks.

In his descriptions, Davidson $(1848,1866)$ mixed the morphology of $O$. forbesii with that of Acrosaccus woolhopensis sp. n. Davidson (1866, pl. 7, fig. 16a), adding the ventral valve to this dorsal one to illustrate an ideal profile of a complete specimen of $O$. forbesii. He probably used the specimen in fig. 15a (=Acrossacus woolhopensis) as the model, but the profile of the shell is confusing. Unfortunately, the dorsal valve figured by Davidson (1848, pl. 3, fig. 45, third from right) and Davidson (1866, pl. 7, fig. 16), which is probably the earliest figured specimen of $O$. forbesii, is not available for study. Davidson (1848) defined $O$. forbesii based on three specimens from Dudley, all from the collection of John Gray, but did not select a holotype. Cocks (1978, p. 27) selected the ventral valve (B796) collected by John Gray as the lectotype of Orbiculoidea forbesii. This specimen, possibly figured by Davidson (1848, pl. 3, fig. 45, second from right; unfigured by Davidson in 1866), is currently stored in the collections of the Natural History Museum. However, this specimen belongs to Acrosaccus woolhopensis. It is worth noting that two other ventral valves have the same number (B796) and are labelled "Malvern".

The small shell figured by Davidson (1866, pl. 7, fig. 17) is a deformed, weathered, articulated discinid specimen (B14287). It shows part of the original thin shell, which has prominent concentric rugellae separated by broader, flat interspaces. However, it cannot be confidently referred to $O$. forbesii or other discinid species. It should be noted that the specimen figured by Rowell (1965a, fig. 178, 7) and Holmer \& Popov (2000, fig. 43, 2a-c) to illustrate the type species of the genus Orbiculoidea d'Orbigny, 1847 does not belong to $O$. forbesii, but probably to Acrosaccus cocksi sp. n. The specimen referred by Whittard \& Barker (1950) to O. forbesii from the Telychian (Llandovery) Hughley Shales of Shropshire probably also belongs to another species, as it has a more central ventral apex, a slightly coarser ornament, and is of a smaller size than $O$. forbesii.

Distribution. - Wenlock, Homerian; Much Wenlock Limestone Formation; Welsh Borderland, Hereford, Malvern Hills; West Midlands, Dudley, Wren's Nest.

\section{Genus Rugadiscina gen. n.}

Type species. - Orbicula rugata J. de C. Sowerby in Murchison, 1839; Silurian, Ludlow, Ludfordian; Ludlow, England.

Name. - Latin, ruga, referring to the wrinkled type of ornament. 
Diagnosis. - Convexoplane, thick-walled discinid with short pedicle track surrounded by a depression, anteriorly closed by broad, short listrium, internal pedicle tube very short; posterior part of ventral valve entirely mineralised, with same ornament as rest of the valve; dorsal valve with submarginal apex, weakly defined visceral area and thin myophragm; ornament of regular, high, lamellose rugellae.

Remarks. - This new genus belongs to a group of convexoplane to convexoconcave discinids that are generally poorly known. The genus Orbiculoidea d'Orbigny, 1847 differs from the new genus in its long pedicle track with narrower listrium and slightly asymmetrical ventral valve. The outline of Orbiculoidea is subtrapezoidal in its posterior part, but evenly rounded in Rugadiscina. Acrosaccus Willard, 1928 and Schizotreta Kutorga, 1848 have a conical ventral valves. Kosoidea Havlíček \& Mergl, 1988, Lindstroemella Hall \& Clarke, 1890, Oehlertella Hall \& Clarke, 1890, Praeoehlertella Mergl, 2001, are described with a posteriorly open pedicle track or are poorly known (Lingulodiscina Whitfield, 1890). The species Discina rugata (J. de C. Sowerby, 1839) cannot be accommodated into any of these genera because it has a planar ventral valve with a well mineralised posterior ventral valve. Another discinid genera with planar ventral valve and mineralised posterior, such as the North American Devonian genus Roemerella Hall \& Clarke, 1890, have a concave ventral valve profile with the pedicle track on an elevated area.

Other differences concerning the microornament, which is characterised by distinct radial rows of larger pits or hollow tubercles in R. rugata, but consists of irregularly spaced, uniform, smaller pits in Orbiculoidea.

Species referred. - At present, only the type species may be definitely referred to the new genus.

\section{Rugadiscina rugata (J. de C. Sowerby, 1839) Figure 7A-N}

1839 Orbicula rugata J. de C. Sowerby; Sowerby in Murchison, p. 610, pl. 5, fig. 11.

1854 Orbicula rugata J. de C. Sowerby, in Murchison. Murchison, pl. 20, figs 1, 2.
1859 Discina rugata J. de C. Sowerby, in Murchison. Murchison, pl. 20, figs 1, 2.

1866 Discina rugata Sow. (sp.). - Davidson, p. 63, pl. 5, figs 9-17 (not 18).

1867 Discina rugata J. de C. Sowerby, in Murchison. Murchison, pl. 20, figs 1, 2.

1872 Orbicula rugata J. de C. Sowerby, in Murchison. Murchison, pl. 20, figs 1, 2.

1902 Orbicula rugata J. de C. Sowerby. - Blake, p. 6.

1963 Orbiculoidea rugata (J. de C. Sowerby). - Holland et al., p. 154, pl. 6, fig. 10 .

1978 Orbiculoidea rugata (J. de C. Sowerby, 1839). Cocks, p. 27, 174.

1986 Orbiculoidea rugata (J. de C. Sowerby, in Murchison, 1839). - Basset, p. 93, text-fig. 18-1F-I.

Lectotype. - Selected by Cocks (1978), the ventral valve (BGS Coll. 6634 B) figured by Sowerby, in Murchison (1839, pl. 5, fig. 11, left-hand), refigured by Davidson (1866, pl. 5, fig. 9) and by Bassett (1986, text-fig. 18-1F); refigured here in Fig. 7I.

Type horizon. - Silurian, Ludlow, Ludfordian.

Type locality. - Shropshire, Ludlow, Whitcliffe ('Ludlow promontory').

Material. - Thirty-seven dorsal and 22 ventral valves from various collections in the Natural History Museum (specimens 26069, 26069, 26069A, 26069B, 33022, 33022A, 97857, 97857A, B10202, B10207, B10209, B10210, B10211, B1106, B11570, B24091, B24091A, B24093, B3045, B3045A, B3073, B3074, B3117, B3118, B3119, B3119A, B34888, B3546, B3548, B50009, 50010, B5899, B5899A, B5899B, B5900, B5900A, B5900B, B74725, B74726, B74727, B811, B812, B813, B84497, BB3408A, BB65639, BB67392, ВB67393, BC50006, BC5007, BC50011, BC50012).

Description. - The shell is convexoplane, rectimarginate, of moderate size, $13-15 \mathrm{~mm}$ wide in adult specimens, thick-shelled relative to the shell size. The outline is almost circular, with margins evenly curved. The length/width ratio is close to 1.0 , the length never exceeds the width (except in deformed specimens). The maximum width occurs at mid-length.

Figure 6. Orbiculoidea forbesii (Davidson, 1848). Wenlock, Homerian, Much Wenlock Limestone Formation, localities Malvern (A, D, F-N), Dudley (B, C , E , O). • A, D , G , J - complete shell, ventral valve (A) and oblique view (D), dorsal valve (G), and side view of complete shell (J), B74389, all × 2.0. • B, C, E, O - neotype, complete shell, ventral valve showing pedicle track (B), oblique view (E), detail of pedicle track (C), and pitted microornament of dorsal valve exterior (O), B818, possibly the articulated specimen figured by Davidson (1848, pl. 3, fig. 45, first from right), refigured by Davidson (1866, pl. 7, fig. 16a, bottom), $\times 3.0, \times 2.0, \times 3.0, \times 125 . \bullet \mathrm{F}-$ small dorsal and ventral valves, likely of the same juvenile specimen, B47850, $\times 3.5$. $\bullet \mathrm{H}, \mathrm{K}, \mathrm{M}, \mathrm{N}-$ dorsal valve, dorsal $(\mathrm{H})$, oblique $(\mathrm{K})$, lateral $(\mathrm{M})$, and posterior $(\mathrm{N})$ views, B74389, all $\times 2.0 . \bullet \mathrm{I}, \mathrm{L}-$ dorsal valve, and detail of ornament, B34793, $\times 2.0$, $\times 6.5$. 
Michal Mergl • British Silurian discinoid brachiopods
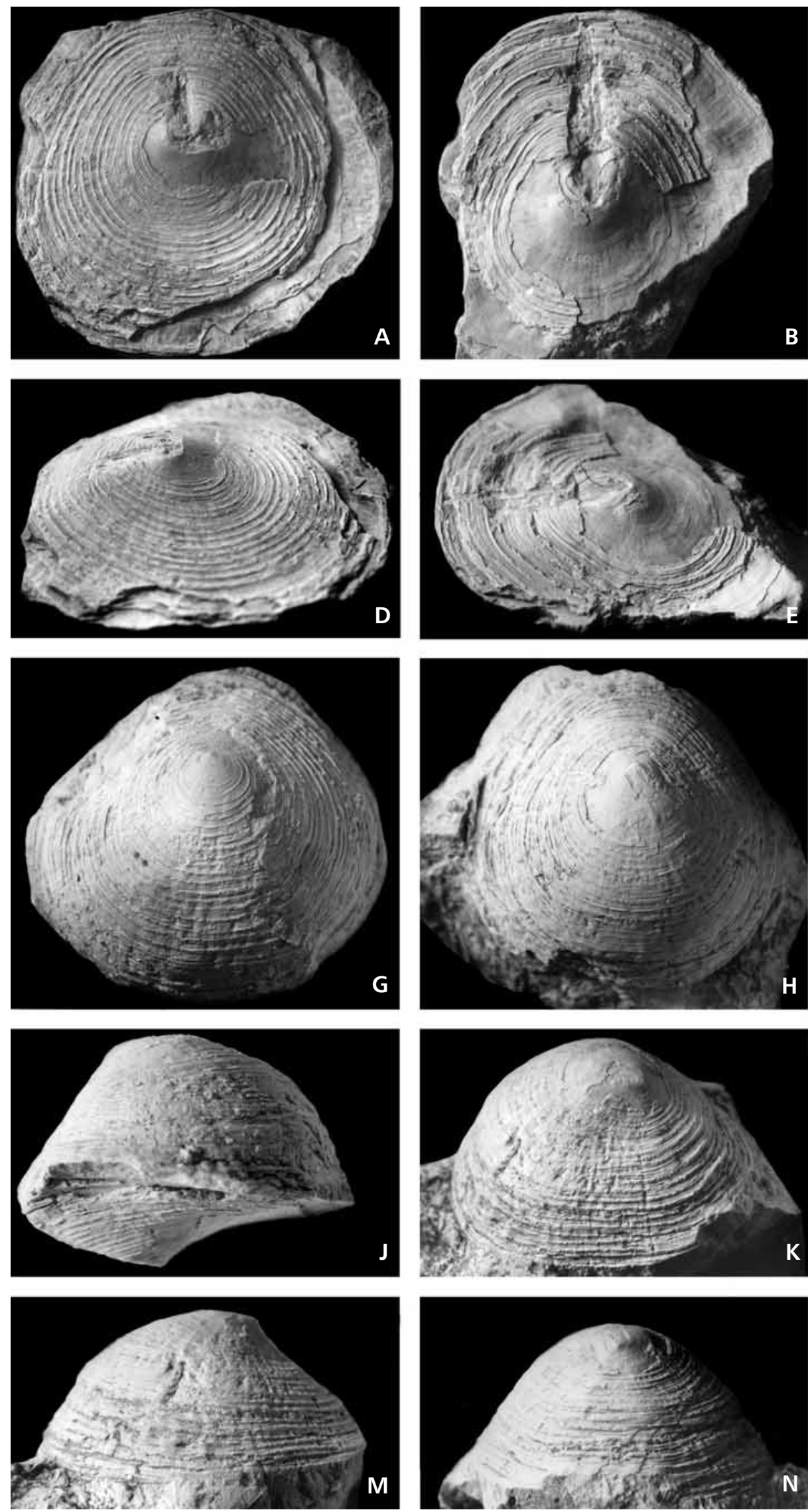
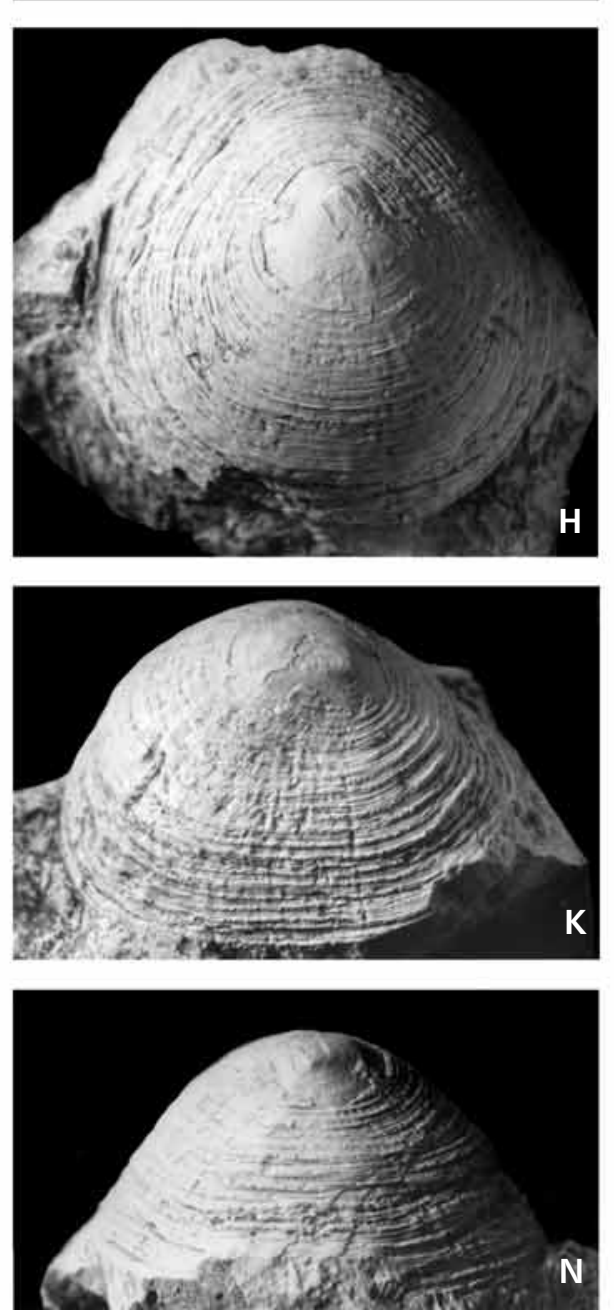

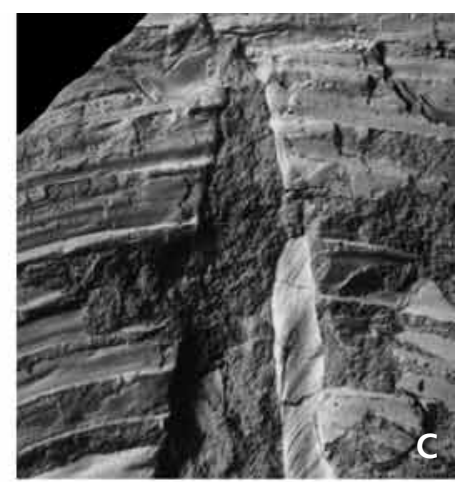

.
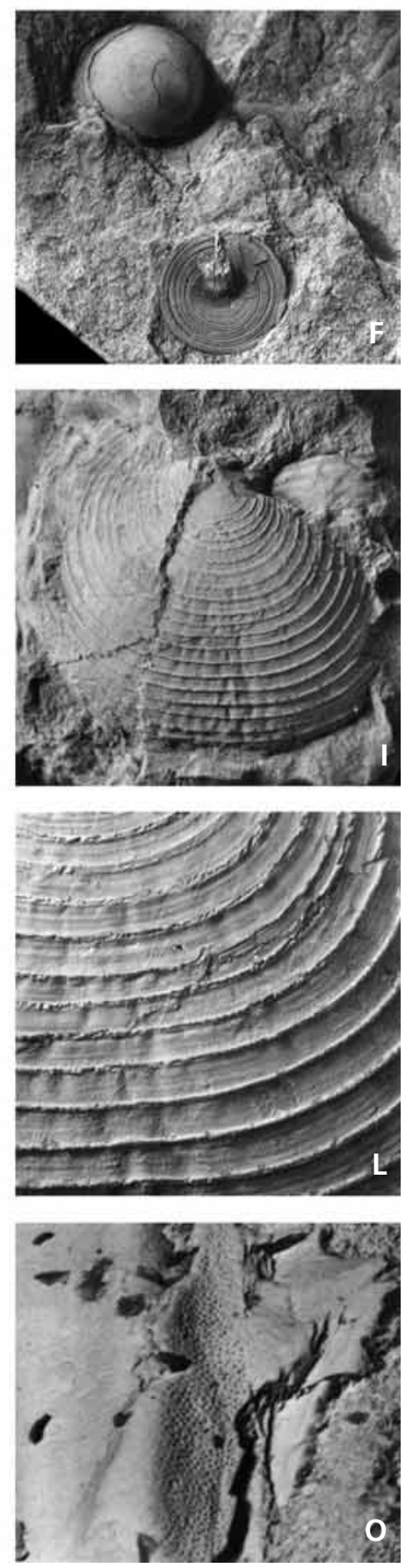
The dorsal valve is strongly convex, its height is about $30 \%$ of its length. The apex lies in the posterior $15 \%$ of the valve length, and is directed posterodorsally to almost posteriorly, depending on the age of the specimen. The posterior slope is weakly concave, the anterior slope is evenly convex, the lateral slopes somewhat less so. A weakly flattened narrowly triangular area with less prominent ornament is visible immediately posterior to the apex, but it rapidly becomes obscure. The dorsal interior is weakly impressed, and has a remarkably small visceral area near the apex. Small pairs of oblique lateral and anterior adductors are poorly impressed. An additional pair of minute scars, probably posterior adductors, are located at the bottom of the posterior slope. The visceral area is divided by a thin, low median ridge. Vascula media moderately divergent and thin, and only their proximal parts being impressed. Vascula lateralia are much broader, with only impressed short proximal parts.

The ventral valve is flat to resupinate in late adults, with a subcentral, always weakly posteriorly situated apex. The apex is almost flat and rests on a weakly convex apical region. The posterior slope is weakly convex, the anterior slope is weakly convex in its apical part, becoming straight and concave anteriorly in large shells. The pedicle opening lies at the posterior extremity of the deep and wide pedicle track, which occupies about half of the length of the posterior slope, and has steep lateral slopes covered by the same concentric ornament as the rest of the shell. The anterior bottom of the depression is covered by a broadly triangular listrium with a flat narrower median, broader, deeply concave outer parts. The posterior extremity of the pedicle track forms an acute angle. It continues as a very short pedicle tube to the shell interior. The ventral valve interior is devoid of well defined muscle impressions. A short, very fine myophragm is seen in some valves immediately anterior to the apex. A fine, narrow groove extends from the internal pedicle opening to almost the posterior margin of the valve. Vascular system is complex, formed by numerous uniform and radially disposed canals; at their mid-length dichotomously and repeatedly branching into numerous fine canals perpendicular to the shell margin. There are 15-20 terminal canals per $\mathrm{mm}$ along the shell periphery. A narrow elevated concentric pad caused by the fine imprints of the setal follicles divides the canals.
The surface of the dorsal valve is covered by prominent, regularly spaced, concentric rugellae between 0.2 and $0.5 \mathrm{~mm}$ apart, averaging $0.3-0.4 \mathrm{~mm}$. There are $10-15$ rugellae per $5 \mathrm{~mm}$. The rugellae are generally high $(0.10-0.12 \mathrm{~mm})$, resting perpendicularly on the shell surface. New rugellae originate by intercalation in the lateral sectors. The posterior part of the dorsal valve displays slightly finer and lower rugellae than the anterior part. The ornament of the ventral valve is similar, with rugellae weakly inclined toward the periphery of the valve. The rugellae in the apical part are delicate, but they soon reach the average size and remain at an almost constant size during growth. Micro-ornament of raised hollow tubercles is often preserved as circular pits with raised margins. Preserved pits are arranged into radial rows anteriorly and laterally, but posterolaterally the radial rows become less discrete and the pits have an irregular arrangement. The pits are $3-4 \mu \mathrm{m}$ in diameter and their size is constant over the entire shell.

Remarks. - Davidson (1866) referred ten specimens to this species. Of these, the figures 9 and 10 in his plate 5 were redrawn from Murchison (1839). The lectotype in figure 9 (BGS Coll. 6634B) and the dorsal valves in figures 14, 15, 16 are housed in the collections of the British Geological Survey in Keyworth (BGS 16819, BGS 4801, and BGS 6634A). The dorsal valve in his figure 13 (BB34084) and the ventral valve in figure 17 (B5900A) are in the collections of the Natural History Museum. Apart from these specimens, Davidson's collection includes five other specimens (dorsal valve external mould B5900 B; dorsal valve external mould B5900 C; dorsal valve internal mould B5899 A; dorsal valve internal mould, B5899 B; ventral valve B5899 C), none of which can be identified with the figured specimens. In addition, the dorsal valve in Davidson's figures 18 and 18a probably does not belong to R. rugata (J. de C. Sowerby, 1839) but to Acrosaccus coc$k s i \mathrm{sp}$. The specimens in his plate 5, figures 10-12, and 18 cannot be identified among the available specimens and are probably lost.

The presence of Discina rugata (J. de C. Sowerby, 1839) was reported by Barrande (1879; pl. 98, case 1, figs 1-6) in the Wenlock of the Barrandian. However, Rugadiscina rugata (J. de C. Sowerby, 1839) does not

Figure 7. Rugadiscina rugata (J. de C. Sowerby, 1839). Ludlow, Ludfordian, localities Ludlow (A, D, E, G, I-N), Onibury (F), Ledbury (B), Panteg Dingle $(\mathrm{H})$, and Linley Brook (C). • A, L-N - dorsal valve with preserved shell (A), detail of external surface (L), and details of microornament (M, N), BB34084, original of Davidson (1866, pl. 5, figs 13, 13a and 13b), $\times 3.5, \times 22, \times 125, \times 210 \cdot \bullet$ B - dorsal valve, internal mould, B10202, $\times 3.5$. $\bullet$ C - dorsal valve, internal mould with partly preserved shell, B97857, $\times 3.5$. $\bullet \mathrm{D}-$ small ventral valve, external mould with partly preserved shell, B811, $\times 3.5$. $\bullet \mathrm{E}-$ dorsal valve, internal mould showing fine median ridge, B5899, unfigured specimen from Davidson's collection, $\times 3.5 \cdot \bullet F-$ ventral valve, partly exfoliated shell showing fine radial canals of pallial markings, B74727, $\times 3.5 . \bullet \mathrm{G}-$ ventral valve, partly exfoliated ventral interior showing listrium, B5900, original of Davidson $(1866$, pl. 5, fig. 17), $\times 3.5 \cdot \bullet \mathrm{H}-$ ventral valve, B3546, $\times 3.5$. $\bullet \mathrm{I}-$ lectotype, ventral valve, interior, BGS6634B, original by J. de C. Sowerby in Murchison (1839, pl. 5, fig. 11), ×4.0. $\bullet$ J - ventral valve, external mould showings rugate ornament, B3118, ×3.5. $\bullet \mathrm{K}-$ dorsal valve, external mould showing rugate ornament, B24091, × 3.5 . 
Michal Mergl • British Silurian discinoid brachiopods
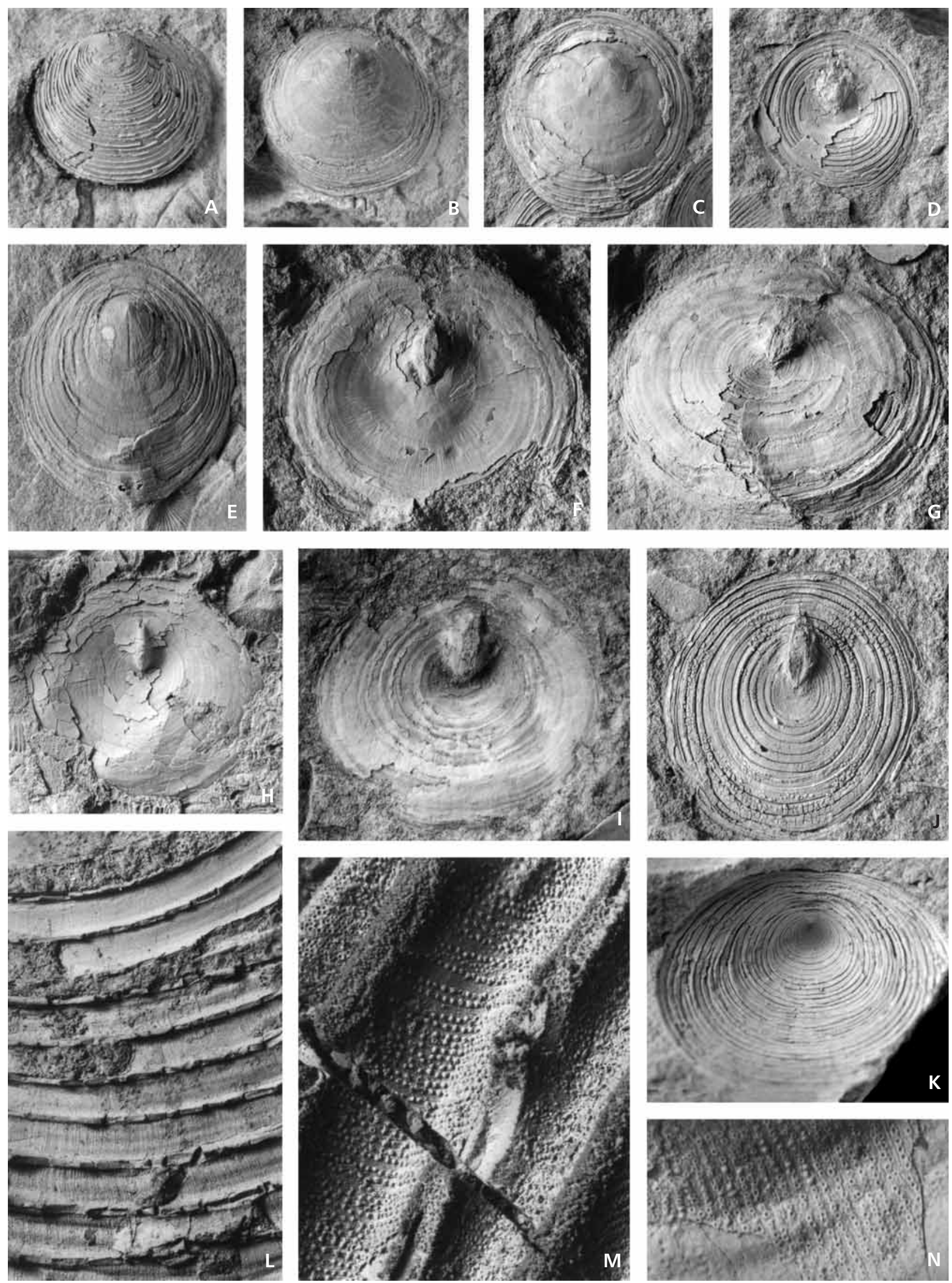
occur in the Barrandian. Examination of Barrande's type material indicates that the specimens in figures 3 and 6 (NM L 24410, NM L 24411) belong to Acrosaccus bubovicensis (Mergl, 2001). The remaining four specimens (NM L 24407, NM L 24408, NM L 24409, and NM L 24412) belong to an undescribed species of Acrosaccus.

Distribution. - Ludlow, Ludfordian; Lower and Upper Whitcliffe formations; Wales, Monmouthshire, Llandesfydd Hill; Powys, Presteign; Shropshire, Ludlow, Cumington (Whitbach farm), Church Stretton (Hungerford farm); Gloucestershire, Norton, Diddlebury, Ledbury.

\section{Genus Lochkothele Havlíček \& Mergl, 1988}

Type species. - Discina intermedia Barrande, 1879; Lochkov Formation; Devonian, Lochkovian; Barrandian, Bohemia.

\section{Lochkothele sp.}

Figure 8A, E

Material. - Three specimens in the collections of the Natural History Museum (C. Birley collection, dorsal valve B23229, from Dudley; G.H. Piper collection, dorsal valve B10154, from Ledbury Tunnel; ventral valve B814, from Hommer Common).

Description. - The shell is ventribiconvex, thin-walled, subcircular, widest slightly anterior to the mid-length. The margins are evenly curved posteriorly and laterally, the anterior margin is less curved. The length/width ratio of single non-deformed ventral valve is 0.83 .

The ventral valve is asymmetrically conical, its height being $40 \%$ of its length. The apex is prominent, directed anteroventrally in the posterior $40 \%$ of shell length. The posterior slope is moderately convex, the anterior slope is concave, with the maximum of concavity near the apex. Lateral slopes are straight. The pedicle track is narrow and deep, occupying $60 \%$ of the posterior slope, with an acute posterior extremity. The pedicle foramen is circular and small. The listrium is small, undivided, and U-shaped in transverse profile. The ventral interior has narrow anterior adductors deeply impressed posterolaterally to the apex.
The exterior is covered by fine concentric fila at nearly regular intervals, coarser on the posterior slope than anteriorly. Interspaces are much broader, with flat bottoms, sometimes with obscure growth lines.

Two unfigured dorsal valves, which may belong to the same species, are strongly deformed. They have posteriorly tapering outlines and submarginal, low, posteriorly directed apices. Divergent narrow vascula media are distinct in the interior. The exterior bears distinct concentric fila, with smooth, wide interspaces of the same type as developed in the ventral valve.

Remarks. - The ventral valve is very similar to Lochkothele intermedia (Barrande, 1879) from the Radotín Limestone of the Lochkov Formation of the Barrandian. The narrow pedicle track, deep and narrow anterior adductor scars, and shell profile are the same. Low, fine concentric fila distinguish Lochkothele sp. from other, mostly coarsely rugellate British discinids. Lochkothele sp. is rare and stratigraphically the earliest known species of the genus.

Distribution. - Wenlock, Homerian; Much Wenlock Limestone Formation; West Midlands Dudley, Wren's Nest; Hereford, Ledbury Tunnel; Hommer Common.

\section{Genus Schizotreta Kutorga, 1848}

Type species. - Orbicula elliptica Kutorga, 1846; Ordovician, Volkhov or Kundan; northwestern Russia.

\section{Schizotreta? cf. rarissima (Barrande, 1879)}

Figure 8B-D, F, G

\section{cf. 1879 Discina rarissima Barr., Barrande, pl. 102, case 5. \\ cf. 2001 Schizotreta rarissima (Barrande, 1879). - Mergl, p. 24 , pl. 17 , fig. 13 .}

Material. - Three specimens in the collections of the Natural History Museum (J.R. Damon collection, dorsal valve B3929, from Dudley; J.F. Walker collection, dorsal valve B34887, from Dudley; dorsal valve B47847, probably from Dudley).

Figure 8. Lochkothele sp. Wenlock, Homerian, Much Wenlock Limestone Formation, locality Homer Common. • A, E - ventral valve (B814) and its oblique view, both $\times 5.5$. Schizotreta cf. rarissima (Barrande, 1879). Wenlock, Homerian, Much Wenlock Limestone Formation, locality Dudley. $\bullet$ $\mathrm{B}$ - dorsal valve, internal mould, B34887, $\times 5.5$. $\bullet$ C - dorsal valve, internal mould, B3929, $\times 5.5 . \bullet D, F, ~ G-$ small dorsal valve, internal mould and detail of ornament, B47846, $\times 5.5, \times 15, \times 75$. Schizotreta walkeri sp. n. Wenlock, Sheinwoodian, Buildwas Formation, Buildwas locality. $\bullet$ H - paratype, dorsal valve, B1086, × 5.5. • I - dorsal valve, B1086, × 5.5. • J - dorsal valve, B1086, × 5.5. • K, M, P - ventral valve, detail of microornament $(\mathrm{K})$, posteroventral view showing the pedicle track $(\mathrm{M})$ and ventral view $(\mathrm{P}), \mathrm{B} 4960, \times 150 . \bullet \mathrm{L}-$ incomplete dorsal valve, B4960, $\times 5.5$. $\bullet \mathrm{N}, \mathrm{O}, \mathrm{Q}-\mathrm{holotype}$, ventral valve with partly exfoliated shell $(\mathrm{O})$, and ventral $(\mathrm{N})$ and posteroventral views $(\mathrm{Q})$ showing the pedicle track, B4960, $\times 5.5, \times 10, \times 15$. 
Michal Mergl • British Silurian discinoid brachiopods
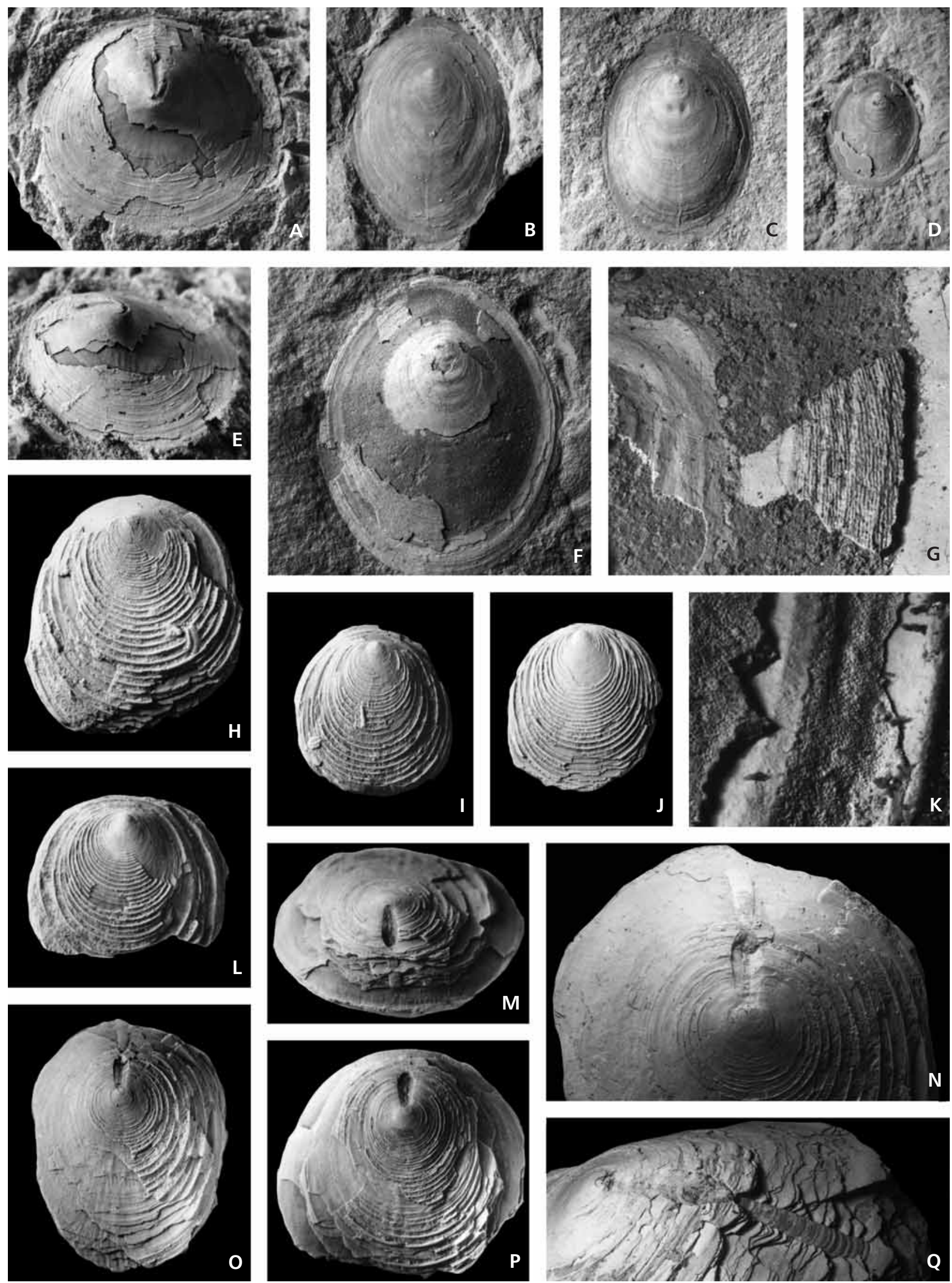
Description. - The British shells are dorsibiconvex, thinshelled, at maximum of $8.5 \mathrm{~mm}$ in length, of elongate elliptical outline, with length/width ratio 1.33-1.40.

The dorsal valve is gently convex (less than $15 \%$ of the length), with the apex in posterior $20-25 \%$ of the length. The posterior slope is slightly concave, the anterior slope is weakly convex. Margins are evenly curved in the posterior part shortly but distinctly elongated. The dorsal interior shows prominent visceral area, extending over the midlength. The pair of oblique anterior adductors and the narrow anterior projection are well impressed. Pallial markings are obscure. The exterior is covered by fine, but remarkably raised and densely packed concentric growth fila.

Remarks. - Barrande (1879) described this species based on a single, poorly-preserved specimen with a broken apical part from the Motol Formation (Wenlock, Sheinwoodian) of Bohemia. Nevertheless, this and another specimen from Bohemia show the same size and profile, the fine but distinct external ornament, and the posterior extension of the dorsal valve as the British specimens.

The species is generally comparable with Schizotreta, but the extended posterior slope and the substitution of a rugellate ornament by very fine concentric lines make this attribution dubious. Similarly shaped paterulids (Paterula Barrande, 1879; Diencobolus Holmer et al., 2001) have a pitted postlarval shell, and their ornament lacks the distinct concentric fila that are present in $S$.? cf. rarissima (Fig. 8G). Because the superficial pitting is unknown in available shells, the systematic positions of the Bohemian $S$.? rarissima and the British $S$.? cf. rarissima will have to be elucidated by new material.

Distribution. - Wenlock, Homerian; Much Wenlock Limestone Formation; England, West Midlands, Dudley, Wren's Nest.

\section{Schizotreta walkeri sp. $\mathbf{n}$.}

\section{Figure $8 \mathrm{H}-\mathrm{Q}$}

Holotype. - Ventral valve, figured in Fig. 8N, O, Q, stored in the paleontological collection of the Natural History Museum, London (B4960).

Paratype. - Dorsal valve, figured on Fig. 8H, stored in the palaeontological collection of the Natural History $\mathrm{Mu}-$ seum, London (B1086).

Type horizon. - Silurian, Wenlock, Sheinwoodian, Buildwas Formation.

Type locality. - England, Buildwas, Buildwas River Section.
Name. - After J.F. Walker, from whose collections the type specimen comes.

Material. - Eighteen specimens in the collections of the Natural History Museum (J.A. Astiae collection, two dorsal and three ventral valves, B20796, from Buildwas; G. R. Vine collection, seven ventral valves, B4960, from Buildwas; J.F. Walker collection, four dorsal and two ventral valves, B1086, from Buildwas).

Diagnosis. - Medium-sized, ventribiconvex, broadly oval Schizotreta with submarginal dorsal apex; ventral valve with the apex in posterior fourth to fifth; convex posterior and straight anterior slope; pedicle track shallow, narrowly triangular, with rounded posterior extremity; ornament of fine concentric rugellae.

Description. - The shell is ventribiconvex, rectimarginate, thick-shelled, with numerous laminae in the wall, $9 \mathrm{~mm}$ long in the largest specimen. The outline is broadly oval, with the maximum width at mid-length, with length/width ratio about 1.4 .

The dorsal valve has a regularly rounded outline. The apex is submarginal, separated by a very short but steep, straight slope from the posterior margin, while the anterior slope is straight and almost flat anteriorly. The valve is gently convex in transverse profile. The dorsal valve interior is devoid of a clearly defined visceral area and pallial markings.

The ventral valve is asymmetrical and slightly conical, with the apex directed ventrally and situated in the posterior fourth to fifth of the valve length. The height of the valve is about $30 \%$ of the valve length. The posterior slope is gently convex and almost perpendicular to the commissure plane in large specimens. The anterior slope is almost straight. The larval shell is circular, and not intersected by the pedicle track. The pedicle track is narrowly triangular, narrow apically but expanding posteriorly and its posterior extremity is broadly rounded. Its length is some $40-50 \%$ of the posterior slope. The external pedicle opening is circular, large and continued internally by the distinct, weakly expanding pedicle tube, which extends almost to the posterior margin of the shell (Fig. 8Q). Muscle imprints or pallial markings were not observed.

The ornament is comprised of elevated, high rugellae, separated by wider, almost flat interspaces. The size of the rugellae and the width of the interspaces regularly increase during growth. New rugellae originate by intercalation in the lateral sectors, but there is no size difference between entire and intercalated rugellae. Microornament of minute, densely and irregularly spaced pits, which are ca $4 \mu \mathrm{m}$ in diameter.

Remarks. - The new species differs from previously described Silurian discinids from England and Wales in its 
elongate outline and small size. All known Silurian discinids from Bohemia differ in their more anterior dorsal apex. In size and convexity, the small specimen of Orbiculoidea forbesii Davidson, 1848 figured by Davidson (1866, pl. 7, fig. 17) is somewhat reminiscent of Schizotreta walkeri. However, Davidson's specimen has a thin shell, subcentral dorsal apex, and finer concentric rugellae, which indicates of another species.

All available shells of the new species are probably derived from the very fossiliferous grey and olive-green siltstones and shales that produced numerous specimens of corals, brachiopods, trilobites, ostracods, bryozoans and other groups during the nineteenth century (Aldridge et al. 2000).

Distribution. - Wenlock, Sheinwoodian; Buildwas Formation; England, Shropshire, Buildwas, Buildwas River Section.

\section{Acknowledgements}

I am greatly indebted to S. Long and L.R.M. Cocks of the Natural History Museum in London for access to the material, and for their help and critical comments; to M.G. Bassett, L. Popov, M. Sutton, A.J. Boucot and R.B. Blodgett for valuable critical comments and discussion; M. Howe, P. Shepherd, and P. Taylor for help with Murchison's and Davidson's material in the British Geological Survey; and to A. Ball and C. Jones from the Natural History Museum for assisting with the SEM study of the material. This research was supported by the European Commission's Framework 5 Programme by SYS-RESOURCE in 2002.

\section{References}

Aldridge, R.J., Siveter, David J., Siveter, Derek J., Lane, P.D., PALmer, D. \& Woodcock, N.H. 2000. British Silurian Stratigraphy. 542 pp. Joint Nature Conservation Committee, Peterborough.

BARRANDE, J. 1879. Systême silurien du Centre de la Bohême. I ìre partie: Recherches Paléontologiques. Volume 5. Classe des Mollusques. Ordre des Brachiopodes. 226 pp. Prague and Paris.

Barrois, C., Pruvost, P. \& Dubois, G. 1922. Brachiopodes. In Description de la faune siluro-dévonienne de Liévin. Mémoires de la Société géologique du Nord 6(2), 71-104.

BASSETT, M.G. 1986. Brachiopodes inarticules. In RACHEBOEUF, P.R. (ed.) Le Groupe Liévin, Pridoli - Lochkovien de l'Artois (N. France). Biostratigraphie du Paléozoique 3, 85-97.

BLAKE, J.F. 1902. List of the types and figured specimens recognised by C.D. Sherbern, F.G.S., in the collection of the Geological Society of London. London Geological Society.

CALEF, C.E. \& HANCOCK, N.J. 1974. Wenlock and Ludlow marine communities of Wales and the Welsh Borderland. Palaeontology 17, 779-810.
Clarke, J.M. 1913. Fósseis devonianos do Paraná. Monographias do Servico Geologico e Mineralogico do Brasil 1, $1-353$.

Cocks, L.R.M. 1978. A review of the British Lower Palaeozoic brachiopods, including a synoptic revision of Davidson's Monograph. Monograph of the Palaeontographical Society London 549, part of vol. 131 for 1977, $256 \mathrm{pp}$.

CocKs, L.R.M. \& ToRSVIK, T.H. 2002. Earth geography from 500 to 400 millions years ago: a faunal and palaeomagnetic overview. Journal of the Geological Society, London 159, 631-644.

CoOPER, G.A. 1956. Chazyan and related brachiopods. Smithsonian Miscellaneous Collection 127, 1-1245.

DAVIDSON, T. 1848. Mémoire sur les brachiopodes du système silurien supérieur de l'Angleterre. Bulletin de la Société géologique de France (série 2) 5, 309-338, 370-374.

DAVIDSON, T. 1866. A monograph of the British fossil Brachiopoda. Part. VII, No. I. The Silurian Brachiopoda. Monograph of the Palaeontographical Society, London 19 (for 1865), $1-88$.

GRAY, J.E. 1840. Synopsis of the contents of the British Museum, $42^{\text {th }}$ edition. 370 pp. British Museum, London.

Hall, J. 1847. Palaeontology of New York, vol. 1. Containing descriptions of organic remains of the lower division of the New-York System. 338 pp. Charles van Benthuysen, New York.

Hall, J. \& Clarke, J.M. 1890. Extract. Palaeontology of New York 8, Part 1, 120-137. Charles van Benthuysen and Sons, Albany.

HALL, J. \& ClaRKe, J.M. 1892. An introduction to the study of the genera of Palaeozoic Brachiopoda, Part 1.367 pp. New York Geological Survey.

HALl, J. \& WhITFIELD, R.P. 1875. Descriptions of invertebrate fossils, mainly from the Silurian System. Fossils of the Hudson River Group. Geological Survey of Ohio, Report 2 (part 2), 67-110.

HAVLÍČEK, V. 1972. Life habit of some Ordovician inarticulate brachiopods. Věstník Ústředního ústavu geologického 47, 229-234.

HAVLÍČEK, V. 1994. Kosovian inarticulate brachiopods and their ancestors (Late Ordovician, Prague Basin). Věstník Českého geologického ústavu 69, 59-68.

HAVlíčEK, V. \& Mergl, M. 1988. Two new discinid genera (Brachiopoda) from the Silurian and Devonian of the Prague Basin, Czechoslovakia. Věstník Českého geologického ústavu 63, 169-172.

HAVLíčEK, V. \& ŠTORCH, P. 1990. Silurian brachiopods and benthic communities in the Prague Basin (Czechoslovakia). Rozpravy Ústředního ústavu geologického 48, 1-275.

HaVlíčeK, V., VANĚK, J. \& FATKA, O. 1994. Perunica microcontinent in the Ordovician (its position within the Mediterranean Province, series division, benthic and pelagic associations). Sborník geologických věd, Geologie 46, 23-56.

Holland, C.H., Lawson, N.J.D. \& Walsley, V.G. 1963. The Silurian rocks of the Ludlow district, Shropshire. Bulletin of the British Museum (Natural History), Geology 8, 93-171.

HolmER, L.E. 1987. Discinacean brachiopods from the Ordovician Kullsberg and Boda limestones of Dalarna, Sweden. Geologiska Föreningens i Stockholm Förhandlingar 109, 317-326. 
Holmer, L.E. \& Popov, L.E. 2000. Lingulata, 30-46. In WILLiAMS, A., BRUnTON, C.H.C. \& CARLson, S.J. (eds) Treatise on Invertebrate Paleontology, part $\mathrm{H}$, Brachiopoda, Revised, Volume 2: Linguliformea, Craniiformea, and Rhynchonelliformea (part). Geological Society of America, University of Kansas, Boulder, Lawrence. i-xxx, 1-423.

KAYSER, E. 1892. Beitrage zur Kenntnis der Fauna der Siegenischen Grauwacke. Jahrbuch der Köninglichen preussischen geologischen Landesanstalt 2(8), 95-107.

KUTORGA, S.S. 1846. Über das silurische und devonische Schichten-System von Gastschina. Russisch-Kaiserliche Mineralogische Gesselschaft zu St. Petersbourg, Verhandlungen 1845-1846, 85-139.

KuTORGA, S.S. 1848. Über die Brachiopoden-familie der Siphonotretaceae. Russisch-Kaiserliche Mineralogische Gesselschaft zu St. Petersbourg, Verhandlungen 1847, 250-286.

LOCKLEY, M.G. \& ANTIA, D.D.J. 1980. Anomalous occurrences of the Lower Palaeozoic brachiopod Schizocrania. Palaeontology 23(3), 707-713.

Mergl, M. 2001. Lingulate brachiopods of the Silurian and Devonian of the Barrandian. Acta Musei nationalis Pragae, Series $B$ 57, $1-49$.

MERGL, M. 2002. Linguliformean and craniiformean brachiopods of the Ordovician (Třenice to Dobrotivá Formations) of the Barrandian, Bohemia. Acta Musei nationalis Pragae, Series B 58, 1-82.

Mergl, M. \& MASSA, D. 2005. A new giant discinoid brachiopod from the Lower Devonian of Algeria. Acta Palaeontologica Polonica 50(2), 397-402.

MurChISON, R.I. 1839. The Silurian System, founded on geological researches in the counties of Salop, Hereford, Radnor, Montgomery, Caermarthen, Brecon, Pembroke, Monmouth, Gloucester, Worcester, and Stafford; with descriptions of the coalfields and overlying formations. i-xxxii, $768 \mathrm{pp}$. John Murray, London.

Murchison, R.I. 1854-72. Siluria. The History of the oldest known rocks containing organic remains, with a brief rescription of the distribution of gold over the Earth. i-xvi, $1-523$, pls $1-37$ ( $3^{\text {rd }}$ ed., $1859 ; 4^{\text {th }}$ ed., $1867 ; 5^{\text {th }}$ ed. 1872$)$.

D'OrBIGNY, A. 1847. Considérations zoologiques et géologiques sur les Brachiopodes ou Palliobranches. Comptes Rendus Hebdomodaires des Séances de l'Académie des Sciences 25, 193-195, 266-269.

Phillips, J. \& SAlter, J.W. 1848. Palaeontological appendix to Professor John Phillips' memoir on the Malvern Hills, compared with the Palaeozoic districts of Abberly, etc. Memoir of the Geological Survey of Great Britain 2, 331-386.

REED, F.R.C. 1917. The Ordovician and Silurian Brachiopoda of the Girvan District. Transactions of the Royal Society of Edinburgh 5, 795-998.
Rowell, A.J. 1962. Orbiculoidea d'Orbigny, 1847 (Brachiopoda, Inarticulata); Proposed designation of type species under the plenary powers; Z.N.(S.) 1506. Bulletin of Zoological Nomenclature 19(5), 311-314.

ROwELL, A.J. 1965a. Inarticulata. In MOORE, R.C. Treatise on Invertebrate Paleontology, part $H$, Brachiopoda, Volume 1, H260-H269. Geological Society of America and University of Kansas Press, Boulder, Colorado and Lawrence.

Rowell, A.J. 1965b. Inarticulate brachiopoda. In DOUMANI, G.A., BoArdman, R.S., Rowell, A.J., Boucot, A.J., JohnSON, J.G., McAlester, A.L., SAul, J., Fisher, D.W. \& MiLES, R.S. Lower Devonian fauna of the Horlick Formation, Ohio Range, Antarctica. Geology and Paleontology of the Antarctic 6, 241-281.

SCHUCHERT, C. 1893. Classification of the Brachiopoda. American Geologist 11, 141-167.

SOWERBY, J. DE C. 1839. Fossil shells of the lower Ludlow age. In MurChISON, R.I. The Silurian System, founded on geological researches in the counties of Salop, Hereford, Radnor, Montgomery, Caermarthen, Brecon, Pembroke, Monmouth, Gloucester, Worcester, and Stafford; with descriptions of the coalfields and overlying formations. John Murray, London.

SutTon, M.D., BAssetT, M.G. \& Cherns, L. 2000. Lingulate brachiopods from the lower Ordovician of the Anglo-Welsh Basin. Part. 2. Monograph of the Palaeontological Society 154, i, ii, 61-114.

WaAgen, W. 1885. Salt Range fossils, I. Productus-Limestone fossils, Brachiopoda. Memoirs of the Geological Survey of India, Palaeontologia Indica (series 13) 4(5), 729-770.

WATKINS, R. 1979. Benthic community organization in the Ludlow Series of the Welsh Borderland. Bulletin of the British Museum (Natural History), Geology 31, 175-280.

WatKins, R. \& AithiE, C.J. 1980. Carbonate shelf environments and faunal communitites in the Upper Bringewood Beds of the British Silurian. Palaeogeography, Palaeoclimatology, Palaeoecology 29, 341-368.

WHITFIELD, R.P. 1890. Description of a new genus of inarticulate brachiopodous shell. American Museum of Natural History, Bulletin 3, 121-122.

WhitTARD, W.F. \& BARKeR, G.H. 1950. The Upper Valentian brachiopod fauna of Shropshire. Annals and Magazine of Natural History 12, 553-590.

WILLARD, B. 1928. The brachiopods of the Ottosee and Holston formations of Tennesseee and Virginia. Bulletin of the Harvard Museum of Comparative Zoology 68, 255-292.

WiLliams, A. 1974. Ordovician Brachiopods from the Shelve District, Shropshire. Bulletin of the British Museum (Natural History), Geology, Supplement 2, 1-163. 